\title{
Have giant lobelias evolved several times independently? Life form shifts and historical biogeography of the cosmopolitan and highly diverse subfamily Lobelioideae (Campanulaceae)
}

\author{
Alexandre Antonelli1,2
}

\begin{abstract}
Address: ${ }^{1}$ Department of Plant and Environmental Sciences, University of Gothenburg, Box 461, 40530, Göteborg, Sweden and ${ }^{2}$ Present address : University of Zurich, Institute of Systematic Botany, Zollikerstrasse 107, CH 8008, Zürich, Switzerland
\end{abstract}

Email: Alexandre Antonelli - alexandre.antonelli@systbot.uzh.ch

Published: 26 November 2009

BMC Biology 2009, 7:82 doi:10.1 186/1741-7007-7-82

This article is available from: http://www.biomedcentral.com/174I-7007/7/82

(c) 2009 Antonelli; licensee BioMed Central Ltd.

This is an Open Access article distributed under the terms of the Creative Commons Attribution License (http://creativecommons.org/licenses/by/2.0), which permits unrestricted use, distribution, and reproduction in any medium, provided the original work is properly cited.
Received: 29 October 2009

Accepted: 26 November 2009

\begin{abstract}
Background: The tendency of animals and plants to independently develop similar features under similar evolutionary pressures - convergence - is a widespread phenomenon in nature. In plants, convergence has been suggested to explain the striking similarity in life form between the giant lobelioids (Campanulaceae, the bellflower family) of Africa and the Hawaiian Islands. Under this assumption these plants would have developed the giant habit from herbaceous ancestors independently, in much the same way as has been suggested for the giant senecios of Africa and the silversword alliance of Hawaii.
\end{abstract}

Results: Phylogenetic analyses based on plastid ( $r b c \mathrm{~L}, \mathrm{trnL}-\mathrm{F}$ ) and nuclear (internal transcribed spacer [ITS]) DNA sequences for I0I species in subfamily Lobelioideae demonstrate that the large lobelioids from eastern Africa the Hawaiian Islands, and also South America, French Polynesia and southeast Asia, form a strongly supported monophyletic group. Ancestral state reconstructions of life form and distribution, taking into account phylogenetic uncertainty, indicate their descent from a woody ancestor that was probably confined to Africa. Molecular dating analyses using Penalized Likelihood and Bayesian relaxed clock approaches, and combining multiple calibration points, estimate their first diversification at 25-33 million years ago (Ma), shortly followed by several longdistance dispersal events that resulted in the current pantropical distribution.

Conclusion: These results confidently show that lobelioid species, commonly called 'giant', are very closely related and have not developed their giant form from herbaceous ancestors independently. This study, which includes the hitherto largest taxon sampling for subfamily Lobelioideae, highlights the need for a broad phylogenetic framework for testing assumptions about morphological development in general, and convergent evolution in particular.

\section{Background}

When the great 18th-century naturalist Carl Linnaeus took a closer look at a the whale during the preparation of his natural classification system, he realized for the first time that it was not a fish but a mammal [1]. Its form and fins were certainly like the fish, but it also had mammary glands and lungs and should, thus, be classified as a mammal. Ever since Linnaeus, what we today refer to as convergent evolution (see, for example, [2,3]) has been advocated as a common and widespread phenomenon in 
nature. From single features (such as the wings of birds and insects or the cones of cycads and conifers) to whole organisms (shrimps and krill, cacti and euphorbias), superficial similarity has been repeatedly demonstrated to evolve independently in distantly related evolutionary lineages.

In plants, the giant lobelias from the Hawaiian Islands and tropical Africa have been cited as remarkable examples of morphological convergence in the family Campanulaceae (the bellflower family). According to some earlier authors [4-6], convergence from herbaceous plants into tall treelets would have occurred independently in different mountain systems in response to similar tropical alpine climates consisting of nightly frosts and rapid temperature fluctuations. The idea that many morphological features in giant lobelias represent adaptations to proximal environmental factors [7] is based on the observation that the leaf rosettes of many giant species provide insulation for the central axis, protecting the shoot apex and the young leaves and inflorescences from extreme temperatures. According to Hedberg [4], a similar evolutionary pattern can be observed between the giant senecios of Africa and the silversword alliance of the Hawaiian Islands (both in Asteraceae), which Hedberg cited as an example of convergent evolution alongside the giant lobelias (Figure 1).

Since these pioneering works, many studies have addressed specific aspects of giant lobelioids, not only providing novel insights into the conspicuous habit of the giant forms [6] but also their detailed morphology [8-10], chromosome numbers [11,12], conservation status [13] and physiology [14-17]. Based on a phylogenetic analysis of 17 species in subfamily Lobelioideae (including 13 giant forms and four herbaceous taxa), Knox et al. [18] proposed that the giant lobelioids consisted of a Chilean hexaploid group and a pantropical tetraploid group, all derived from herbaceous ancestors. Later, using the Chilean giant species as outgroup and analysing the relationships and biogeographic history among 21 African and one Brazilian giant lobelia, Knox and Palmer [7] suggested that the eastern African giant lobelias arrived in Africa from the Asian/Pacific region. More recently, Givnish et al. [10] used a larger data set (including 38 lobelioid species, of which two are herbaceous) to demonstrate that all Hawaiian lobelioids constitute a monophyletic clade, thus corroborating previous results by Givnish and co-workers [8,19]

Despite these major advances, we still need to verify whether the biogeographic and phylogenetic patterns obtained so far for Lobelioideae will stand the inclusion of increased taxon sampling. In order to confidently test whether the giant forms worldwide evolved independ- ently from herbaceous ancestors, it seems vital to include a considerably larger representation of herbaceous taxa and to root the Lobelioideae tree with representative taxa from outside the subfamily.

Here I build on previous studies to reconstruct the life form and biogeographic evolution of Lobelioideae. I focus on the following questions: (i) have giant lobelioids evolved from herbaceous ancestors several times independently?; (ii) when and where did the giant habit evolve?; and (iii) is the life form and geographic distribution phylogenetically conservative? To address these questions, I generated fast-evolving nuclear sequence data for several giant species and, in combination with all available DNA sequences for selected markers, I performed phylogenetic, biogeographic, character evolution and molecular dating analyses. The results reported here demonstrate that the giant lobelioids have a very different evolutionary history than the giant Asteraceae.

\section{Results and discussion Phylogeny}

The maximum likelihood trees based on all Campanulaceae sequences available at GenBank and complemented by novel sequences generated in this study for trnL-F, ITS and $r b c \mathrm{~L}$ are shown in Figure $2 \mathrm{a}$, c. Lobelioideae is retrieved as monophyletic in all three analyses of each marker separately, providing an indication of the choice of taxa for the subsequent analyses. The results from the Bayesian and bootstrap analyses on the Lobelioideae data set are shown together in Figure 3. Generally, strongly supported relationships were in agreement with, or at least did not contradict, previous phylogenetic analyses [7,8,10,18-21]. The few differences obtained here (especially in clade N4, Figure 3) are discussed below.

\section{Molecular dating}

The results from the molecular dating analyses are summarized in Table 1. Generally, node age estimations exhibited relatively large confidence intervals, both under the Penalized Likelihood (Figure 4) and the Bayesian relaxed clock (Figure 5) methods. The tree with highest sum of clade credibilities generated under the Bayesian evolutionary analysis by sampling trees (BEAST) analysis (Figure 5; effective sample size = 322) did not exhibit any strongly supported phylogenetic conflict with the consensus cladogram of the MrBayes analysis (Figure 3). Although there was great variation between the age estimates obtained in Penalized Likelihood as compared to BEAST, in all key nodes listed in Table 1 there was considerable overlap of the 95\% confidence intervals and highest probability densities. The mean covariance between parental and child lineages in the BEAST analysis was 0.157 (Figure 6a). Since a covariance close to zero indicates no significant autocorrelation of rates (the funda- 


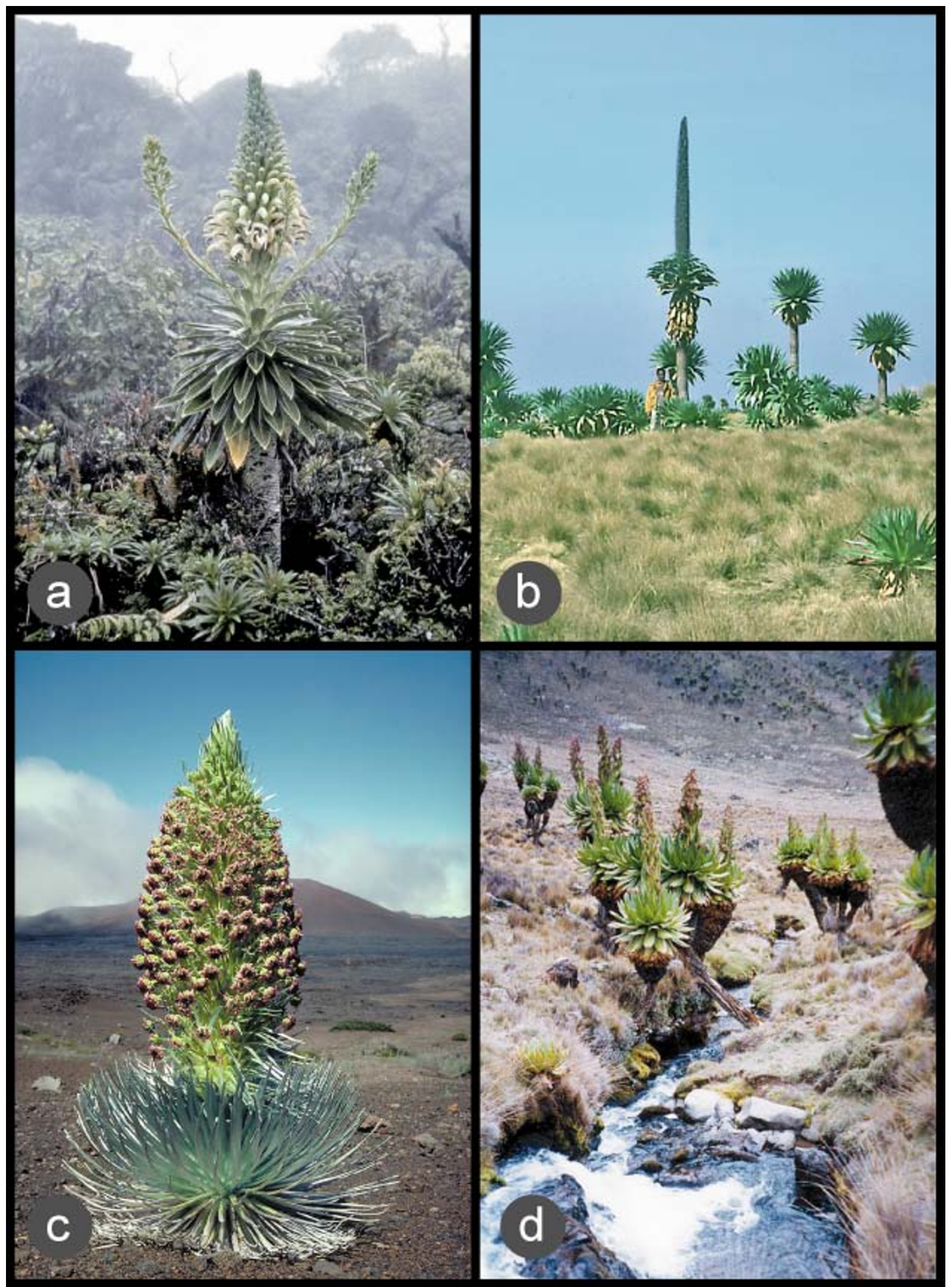

Figure I

Same life form, same history? Giant lobelioids (Campanulaceae: Lobelioideae) from the Hawaiian Islands (a) have been suggested to have converged into the giant life form independently from the giant lobelias of Africa (b), in much the same way as the silversword alliance of Hawaii (c) and the giant senecios of Africa (d) in family Asteraceae. [Credits: a, Lobelia gloria-montis by Frederick R. Warshauer; b, Lobelia rhynchopetalum by Christian Puff; c, Argyroxiphium sandwicense by Gerald D. Carr; d, Dendrosenecio keniodendron, from http://www.wikipedia.org]. 


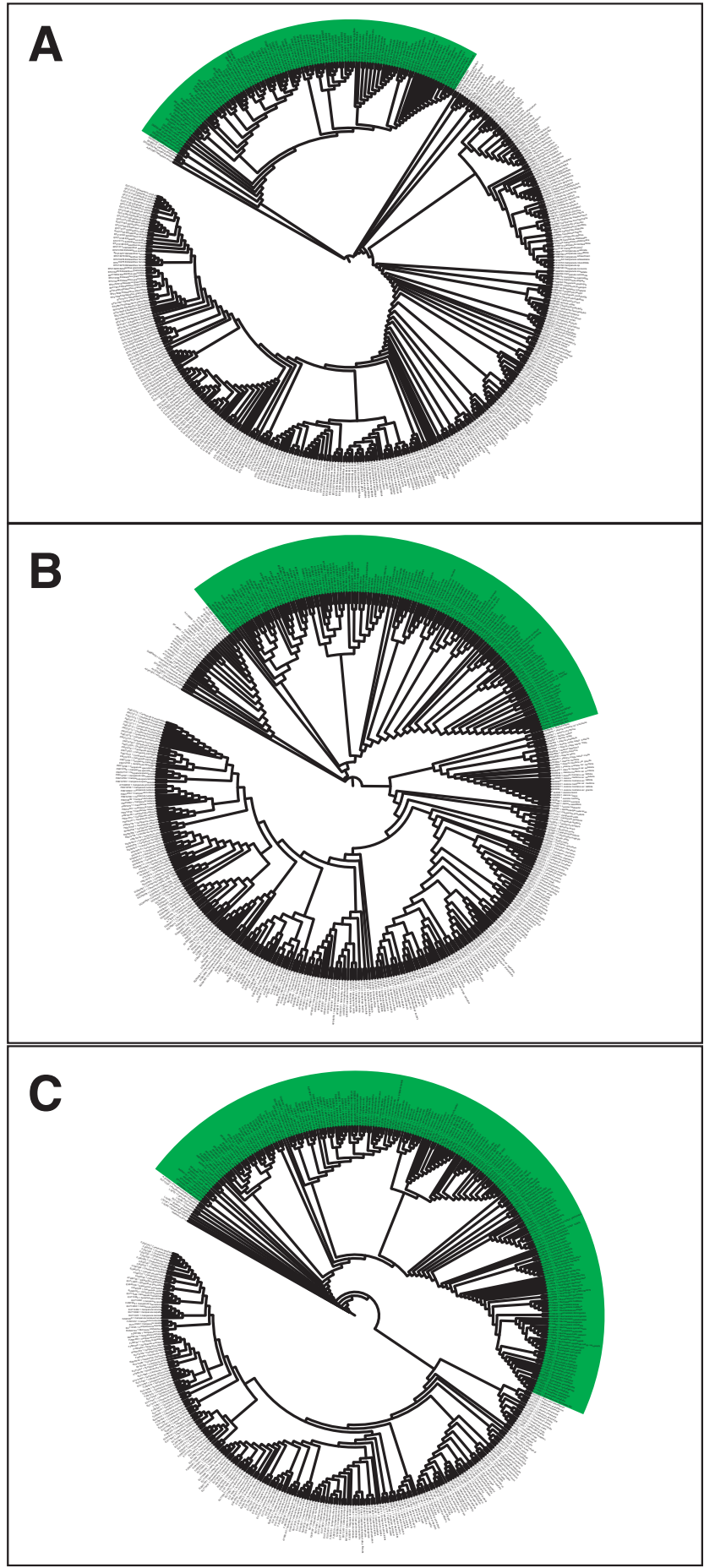

Figure 2

Maximum Likelihood trees of the Campanulaceae. Cladograms with the highest likelihood scores yielded from 10 independent runs in the software GARLI, based on: (a) trnL-F, 452 sequences; (b) ITS, 445 sequences; and (c) rbcL, 438 sequences. Subfamily Lobelioideae is highlighted in green. GenBank accession numbers are given following the species names (as stored in GenBank). mental assumption made by Penalized Likelihood), this indicates that the BEAST results reported here are probably more realistic than the ages obtained in Penalized Likelihood [22]. For comparison, both results are reported throughout the paper.

\section{Life form shifts}

The character state reconstruction of life form is shown in Figure 7 (see Table 2 for the definitions). The reconstruction of life form on the Bayesian cladogram required 68 steps and the character is phylogenetically conservative $(P$ $<0.001$; Figure 8a, b). The ancestral life form of the most recent common ancestor (MRCA) of Lobelioideae (N1 in Figure 3) is ambiguous, due to an early split between a chamaephyte lineage (leading to the clade Lobelia physaloides - L. tomentosa) and a hemicryptophyte lineage (the ancestor to all the others).

There is great life form variation in the Lobelioideae at the intergeneric, intrageneric and intraspecific levels (Figure 7 , Table 3). Only in a few cases is there a homogeneous life form correlating with a certain clade, as indicated by the low Consistency Index of life form overall ( 0.27 on the tree shown in Figure 7). One example of local high consistency is in the clade Lobelia oligophylla - L. arenaria (N11 in Figure 3), in which all exhibit the hemicryptophyte habit, at least facultatively. Although the overall low consistency is partly biased by an uneven taxon sampling (for example, there are only two species of Lysipomia sampled but all 30 species are strictly chamaephytes), it does reflect a general pattern of difficulties in identifying natural taxa in Lobelioideae based on morphology (see, for example, $[21,23])$.

\section{Evolution of the giant lobelioids}

The nanophanerophyte habit (Table 2) developed early in the history of the Lobelioideae, most probably several times (at nodes N4, N10 and N12 in Figure 3; with 81.6\%, $69.1 \%$ and $97.2 \%$ of all reconstructions with uniquely best states, respectively), or, less likely, just once (N3; $45.7 \%$ of all reconstructions; Figure 7, Table 3). Present day lineages inhabiting the Hawaiian Islands, French Polynesia, southeast Asia and eastern Brazil (N4 in Figure 3) all derive from a single ancestor (Bayesian posterior probability, $\mathrm{Bpp}=1.00$, Bootstrap support, $\mathrm{Bs}=98$ ). Ancestral state reconstructions indicate that this ancestor was most likely confined to Africa and that it was a nanophanerophyte (in 950 and 816 of 1000 reconstructions, respectively; the other reconstructions being ambiguous rather than a different state; see Figures 7 and 9). Indeed, it is in this clade that the truly giant habit occurs, as exhibited by L. gloria-montis and L. rhynchopetalum (Figure 1). This corroborates previous results, based on fewer species, that giant lobelias are closely related and are ultimately derived from herbaceous ancestors $[7,18,21]$ but contra- 


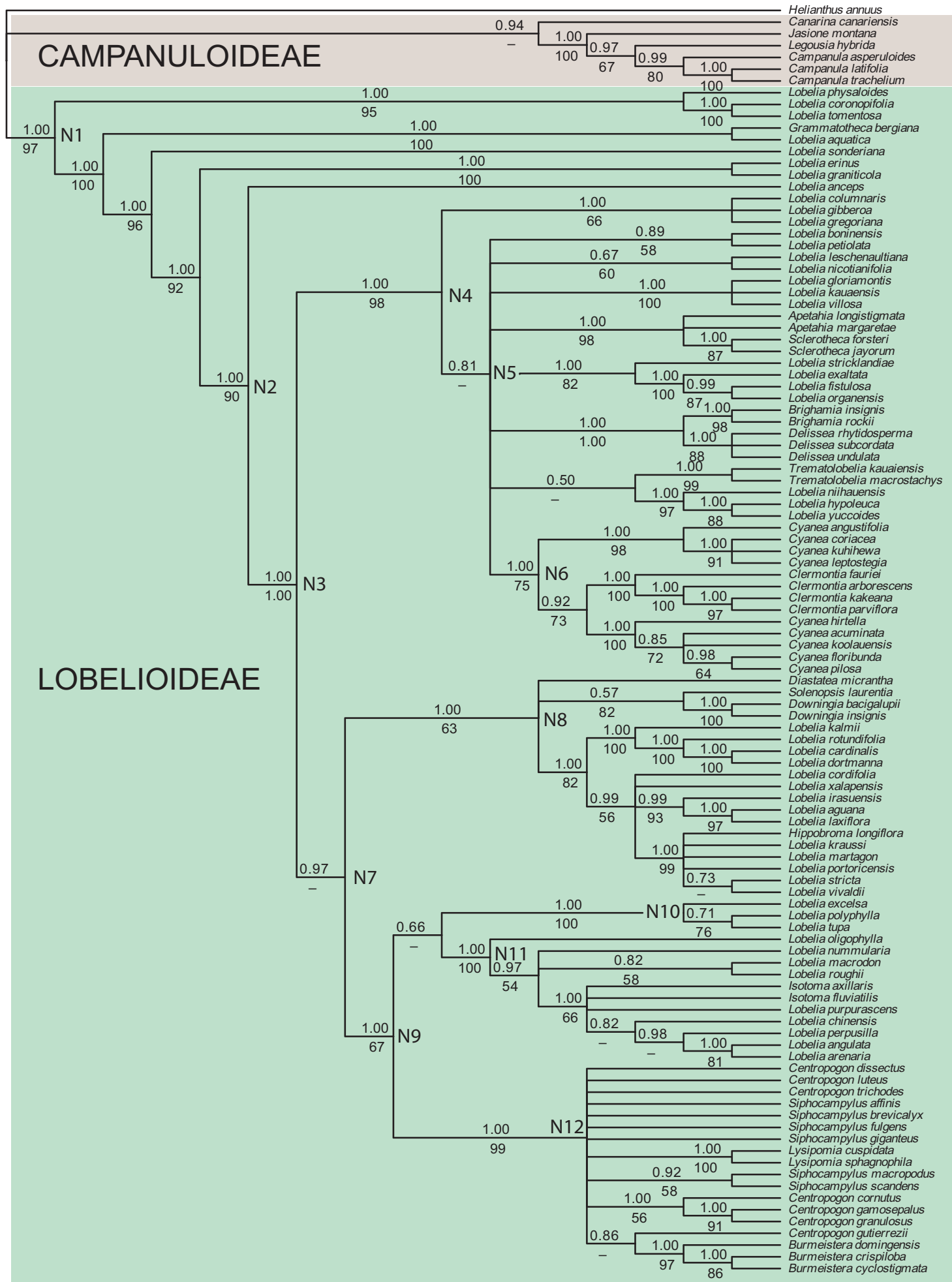

Figure 3

Phylogeny of subfamily Lobelioideae. Fifty-percent majority-rule consensus cladogram from the Bayesian analysis based on the combined data set (trnL-F, ITS, rbcL). Numbers above branches indicate Bayesian posterior probabilities; numbers below branches represent bootstrap support values $(>50)$ calculated under maximum parsimony. Key nodes discussed in the text are labelled NI--N 2 . 


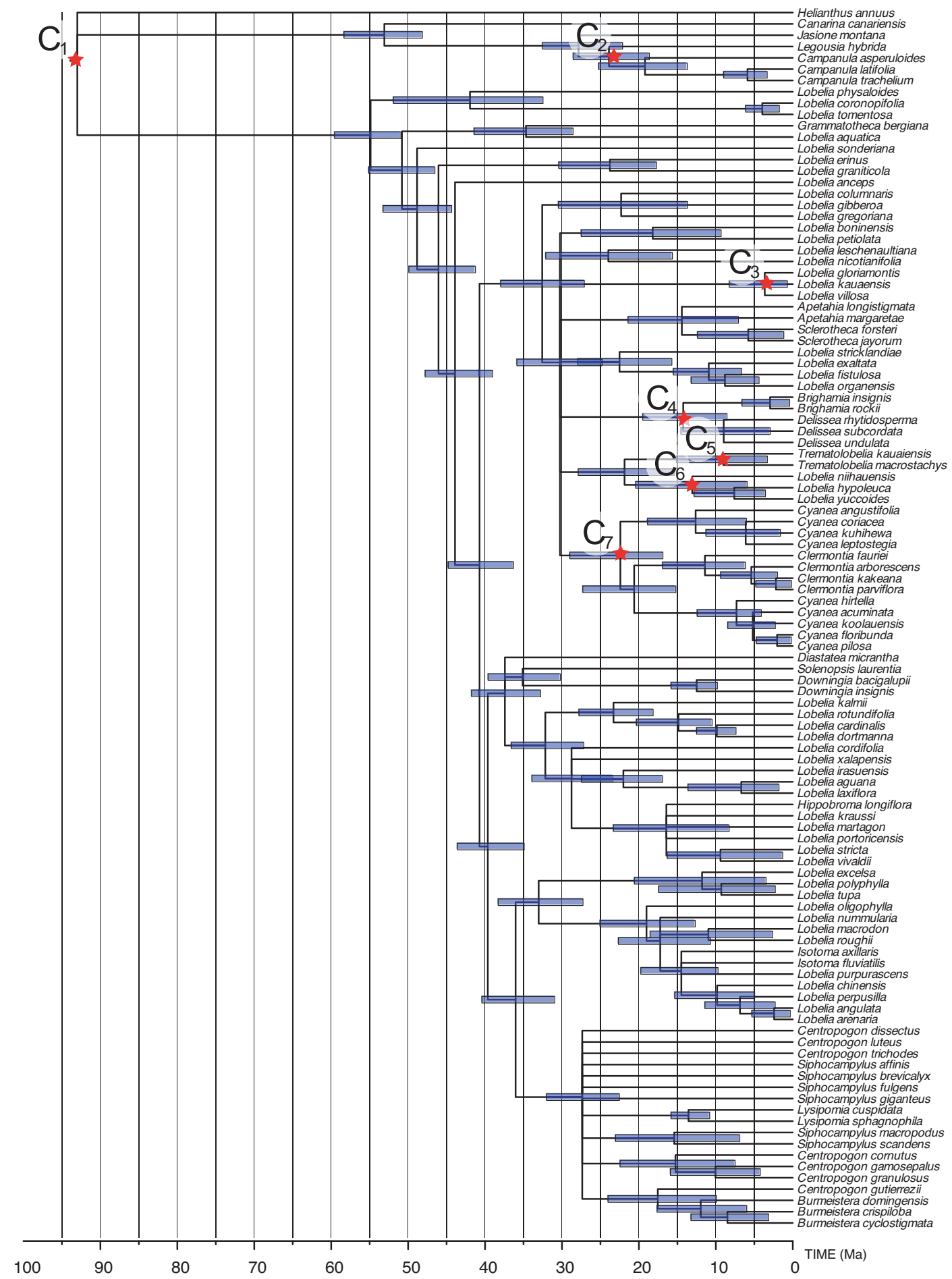

Figure 4

Divergence time estimates using Penalized Likelihood. Mean age chronogram showing $95 \%$ confidence intervals of age nodes (bars), based on 1000 Bayesian trees from a post burn-in tree sample. The stars represent calibration points: $\mathrm{C}_{1}$, crown age of Asterales as estimated by Bremer et al. [66], fixed age $=93 \mathrm{Ma} ; \mathrm{C}_{2}$, crown age of subfamily Campanuloideae, based on a fossil Campanula, minimal age $=5.33 \mathrm{Ma}$ [68]; $\mathrm{C}_{3}-\mathrm{C}_{7}$, diversification of Hawaiian taxa, corresponding to the age of the oldest island of the Hawaiian Ridge (Kure) after which a continuous chain of islands has been available as 'stepping stones' for propagules of the Hawaiian biota, maximum age $=29.8 \mathrm{Ma}[26]$. 


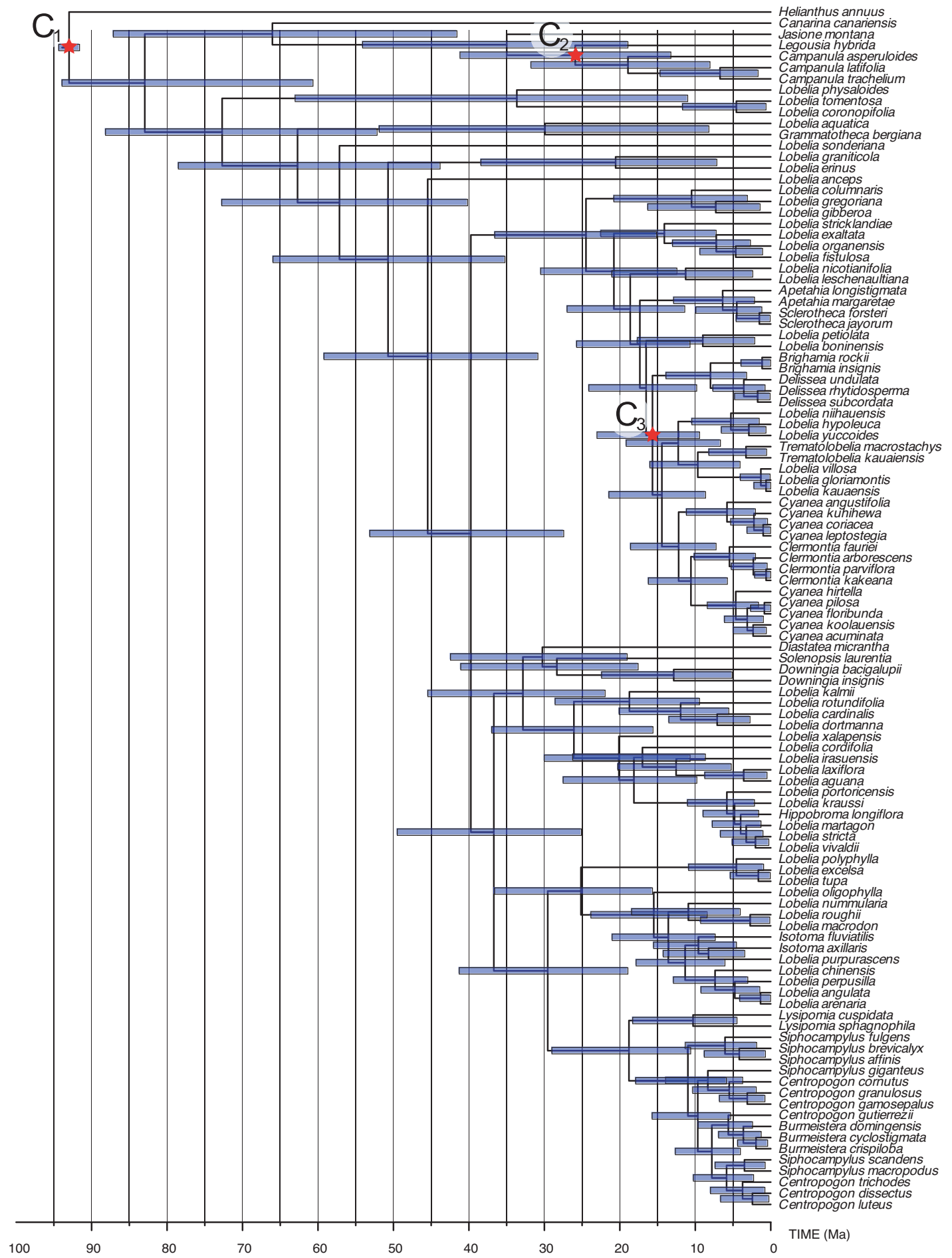

Figure 5

Divergence time estimates using Bayesian relaxed clock (BEAST). Tree, with the maximum sum of clade credibilities and branch lengths equal to the median ages as calculated from 40,000 post burn-in chronograms. Bars show $95 \%$ Highest Posterior Density intervals of age nodes. Calibration points as in the previous figure, with the following exceptions: (i) that the tree prior incorporated for the root of the tree $\left(C_{1}, 93 \mathrm{Ma}\right)$ was not constrained a priori on a particular clade, but allowed to be calculated in the phylogenetic and dating estimation; and (ii) that all Hawaiian species were constrained as monophyletic prior to the analysis, following the results by Givnish et al. [10] (see Methods). 

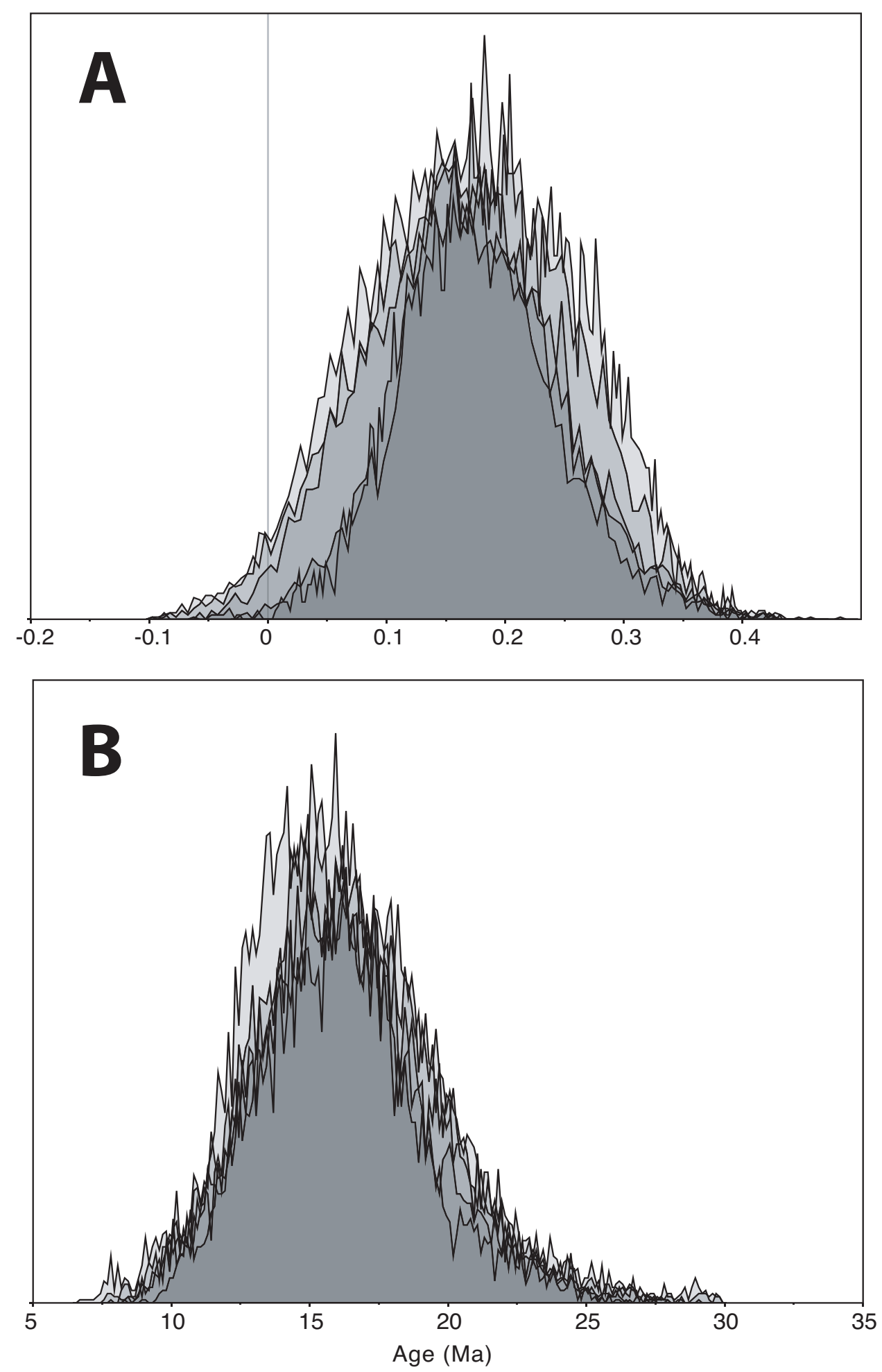

Figure 6

Selected statistics from the BEAST analysis. Distribution curves obtained from a post burn-in sample of 40,000 chronograms; each curve represents an independent run. (a) Covariance between parent and child branch rates. A value close to zero indicates that there is no support for autocorrelation (a main assumption in Penalized Likelihood analyses), meaning that the BEAST results here are probably more realistic. (b) Distribution of age estimates for the crown group of the Hawaiian taxa. 
Table I: Crown group ages (in million of years) of the major groups outlined in Figure 3.

\begin{tabular}{|c|c|c|c|c|}
\hline \multirow[b]{2}{*}{ Clade } & \multicolumn{2}{|c|}{ Penalized Likelihood } & \multicolumn{2}{|l|}{ BEAST } \\
\hline & Mean & $95 \% \mathrm{Cl}$ & Median & 95\% HPD \\
\hline NI & 54.9 & $50.9-59.6$ & 72.7 & $52.2--88.2$ \\
\hline N2 & 43.9 & $39.0--47.8$ & 45.5 & $30.9-59.2$ \\
\hline N3 & 40.7 & $36.3--44.8$ & 39.7 & $27.4--53.1$ \\
\hline N4 & 32.7 & $27.1--38.0$ & 24.5 & I5.| -- 36.6 \\
\hline N5 & 30.3 & $24.8--35.9$ & 20.8 & $12.4-30.5$ \\
\hline N6 & 22.4 & $16.9--29.0$ & 12.2 & $5.74--16.2$ \\
\hline N7 & 39.6 & $34.9--43.6$ & 36.7 & $25.1--49.5$ \\
\hline N8 & 37.4 & $32.8--41.8$ & 32.8 & $22.0--45.4$ \\
\hline N9 & 39.0 & $31.0--40.4$ & 29.6 & $|8.9--4| .3$ \\
\hline NIO & 11.8 & $3.48--20.6$ & 4.56 & $0.95-10.9$ \\
\hline NII & 19.0 & | $2.7-25 . \mid$ & 15.5 & $8.43-23.8$ \\
\hline NI2 & 27.4 & $22.5-32.0$ & 18.8 & $10.6-29.0$ \\
\hline
\end{tabular}

BEAST $=$ Bayesian evolutionary analysis by sampling trees; $\mathrm{Cl}=$ confidence interval; HPD = highest posterior density.

dicts some earlier suggestions the giant habit would be plesiomorphic in the family [6].

Nanophanerophyte ancestors (with buds below $3 \mathrm{~m}$ high; see Table 2) have given rise to phanerophytes (buds above $3 \mathrm{~m}$ ) several times independently. Although several species are strictly phanerophytic (for example, $L$. giberroa, $L$. petiolata, L. stricklandiae, Delissea undulata and Cyanea leptostegia), others often vary in height (for example, Sclerotheca jayorum, Brighamia insignis, Trematolobelia macrostachys, Cyanea angustifolia and Siphocampylus giganteus). These results indicate that, in the Lobelioideae, height seems to be a more labile state than woodiness.

\section{Biogeographic history}

Geographic range development of the Lobelioideae is depicted in Figure 9. As with life form, distribution is phylogenetically conservative $(P<0.001$; Figure $8 \mathrm{c}-\mathrm{d})$, but even more so given its higher consistency index $(0.40)$ and fewer parsimony steps required for reconstructing the Bayesian cladogram (25).

The MRCA of the Lobelioideae, as well as those of most of the early diverging splits (N1 - N3 in Figure 3), are all reconstructed to Africa with confidence. Range shifts are unambiguously inferred from: Africa to Oceania (Lobelia physaloides); Africa to the Neotropics (Lobelia aquatica); the Neotropics to Oceania (Lobelia macrodon - L. arenaria); and Oceania to southeast Asia (Lobelia chinensis). That the Brazilian giant lobelias are together sister to an African species is strongly supported, as previously suggested, by Knox et al. [18].

There is no support here for the hypothesis that the giant lobelias arrived in eastern Africa from Asia or the Pacific region [7]. However, the resolution at the base of clade N4 is very poor and the relationships among the strongly supported clades within it - and possibly their biogeographic reconstructions - may substantially change with the addition of more species and sequence data. Indeed, in the analysis by Givnish et al. [10], L. nicotianifolia (a southeast Asian species) was inferred to be sister to a clade comprising French Polynesian, African and Hawaiian subclades. In the present analysis, that 'basal' position is occupied by African species (L. columnaris, L. gibberoa and L. gregoriana), although the support for this placement is weak (Bpp $=0.81$, Bs < 50). As taxon sampling, sequence regions and phylogenetic methods have all varied considerably between different studies, further investigation is clearly needed in order to reconstruct a solid biogeographic scenario for the large lobelioids.

\section{Dispersal versus vicariance}

Although the exact timing for transcontinental range shifts inferred here are prone to large error margins associated with topological and branch length uncertainties (see the credibility bars at nodes in Figures 4 and 5), all range shifts are estimated to have occurred in the last 50 $\mathrm{Ma}$ and, in several cases, presumably much more recently. Given that the final break-up of Gondwanaland took place around $100 \mathrm{Ma}[24]$, these results provide evidence that long-distance dispersals must have played a major role in shaping the present-day distribution of taxa, a scenario also corroborated by the molecular dating analysis of Givnish et al. [10]. This contrasts to early suggestions [6] that distribution patterns may be the result of vicariance caused by continental drift.

Long-distance dispersal seems plausible for lobelioids, since most species produce large amounts of minuscule seeds. From herbarium specimens, I calculated that $1 \mathrm{~g}$ of seed of the Hawaiian endemic Clermontia kakeana contains about 36,000 seeds (Figure 10). Although seeds of Clermontia and some other Hawaiian genera (Cyanea and Delissea) are today contained in bird-dispersed berries, other Hawaiian taxa (Lobelia, Trematolobelia and Brighamia) still possess wind-dispersed capsules, a condition also inferred for the MRCA of the Hawaiian clade by Givnish et al. [10]. It is therefore reasonable to conclude 


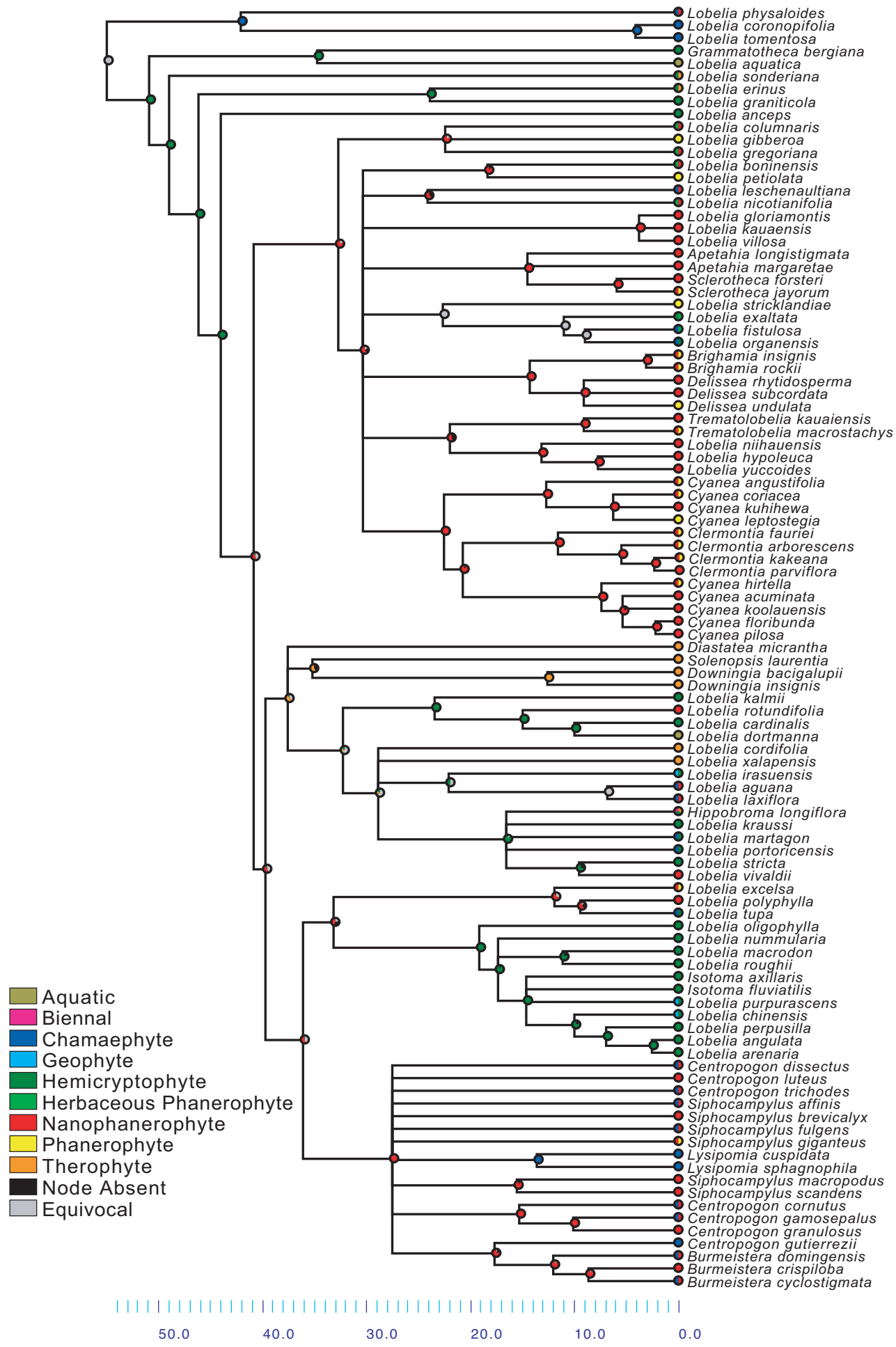

Figure 7

Life form shifts in relation to time. Results from character state reconstructions in subfamily Lobelioideae. The pie charts on each node show the relative proportion of character assignments based on the individual results from the Fitch optimization of 1000 Bayesian post burn-in trees, counting uniquely best states. States of extant species are shown before each species name. Results plotted on the mean age chronogram obtained using Penalized Likelihood (Figure 4). See Table 2 for a definition of life forms. 

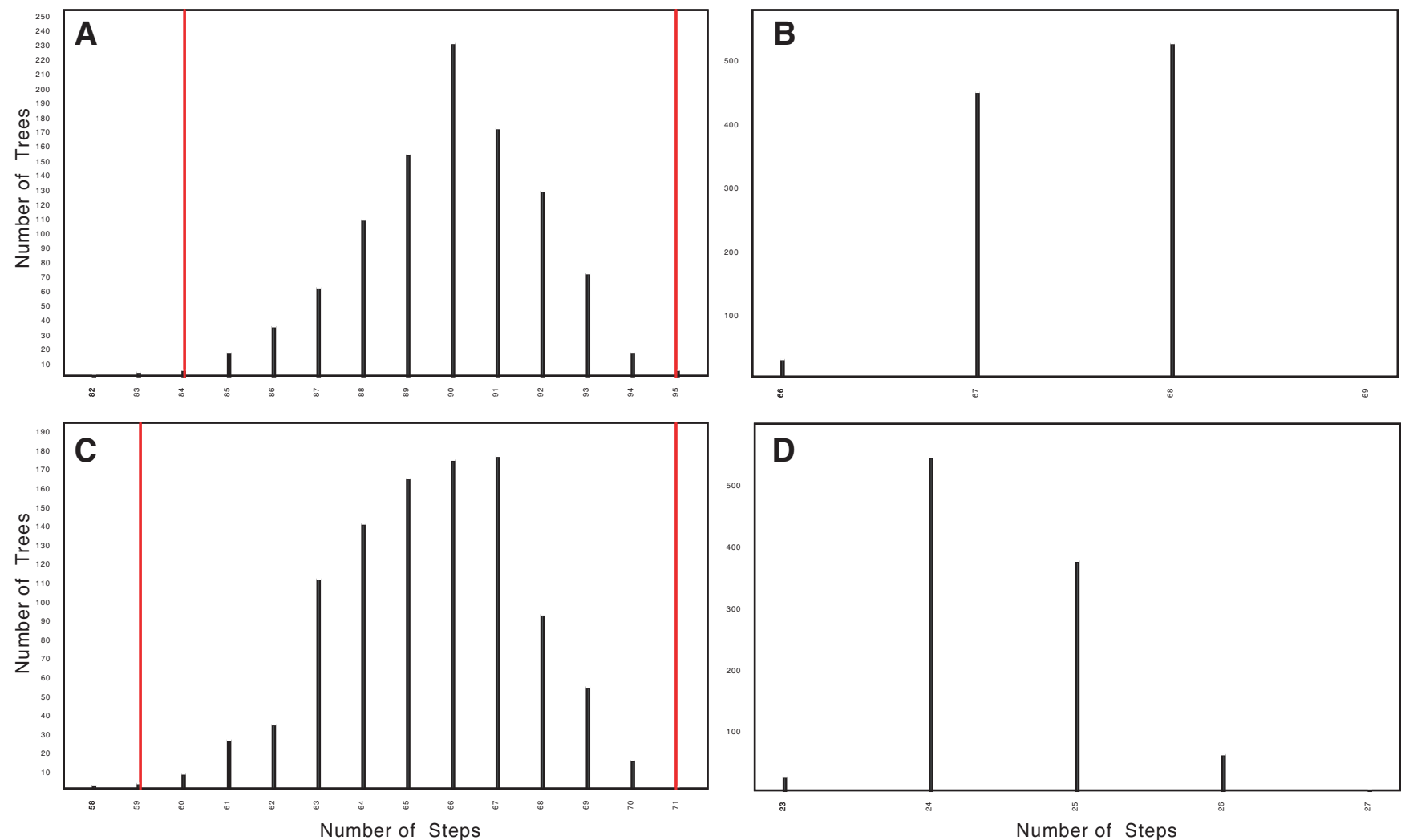

Figure 8

Tests of phylogenetic conservatism in life form and geographic distribution. Comparison of the minimal number of steps required to reconstruct life form and geographic distribution on a sample of 1000 simulated trees (generated by keeping the tree topology as in the Bayesian consensus, but randomly shuffling character states) with 1000 empirical trees (randomly chosen from the post burn-in Bayesian sample). (a) Simulated results for life form; (b) empirical results for life form; (c) simulated results for geographic distribution; and (d) empirical results for geographic distribution. For both characters, the observed values fall outside the lower percentiles of the simulated curves (indicated by the red lines in (a) and (c); $P<0.00 \mathrm{I}$ ), indicating that both life form and geographic distribution are phylogenetically conservative.

that wind dispersal of tiny seeds was the dispersal mode for the ancestor of the Hawaiian lobelioids, as suggested by Givnish et al. [10] and that, presumably, the same applies for other lobelioid dispersal events. Millions of tons of dust are transported annually from the Sahara into South America [25], so it is conceivable that, given enough time, lobelioid seeds could also be carried over the 15,000 km separating the Hawaiian Islands and Africa and, subsequently, succeed in germinating and establishing a new population.

\section{Colonization of the Hawaiian Islands}

The earliest diversification of lineages endemic to the Hawaiian Islands corresponds to the crown age of node N6 retrieved in the MrBayes analysis (Figure 3). In the PL analysis, that clade had a mean of $22.4 \mathrm{Ma}$ (16.9 - 29.0 $\mathrm{Ma}, 95 \%$ confidence intervals, $\mathrm{CI}$ ), whereas in the BEAST analysis the mean was $12.2 \mathrm{Ma}(5.74-16.2 \mathrm{Ma}, 95 \%$ Highest Posterior Density, HPD; Table 1). However, in the
BEAST analysis, where the Hawaiian taxa had to be constrained as monophyletic (see Methods), the crown group of the whole Hawaiian clade had a mean of 16.4 Ma (9.43 - 23.0 Ma, 95\% HPD; see Figure 6b). These ages are only slightly older than the estimates by Givnish et al. [10], which varied between $13.6 \pm 3.11 \mathrm{Ma}$ and $13.0 \pm 1.00$ depending on calibration methodology.

The relatively old node ages estimated here may seem surprising, given that the oldest of the modern Hawaiian Islands with well-developed vegetation only dates back to 5.1 Ma [26]. However, they are fully explainable when considering that these islands are part of a much older archipelago formed by the movement of the Pacific plate over a fixed hot spot. A continuous chain of islands have been elevated since 29.8 Ma [26] and lobelioid lineages could have continuously colonized the rising islands and ceased to exist in the subsiding ones. Island hopping by a plant adapted to long-distance dispersal is biologically 
Table 2: Characterization of life forms used in the ancestral state reconstructions (from Lammers [23]).

\begin{tabular}{|c|c|c|}
\hline Life form & Stems & Buds \\
\hline Aquatic & Comprises both Hydrophytes and Hydrohemicryptophytes & \\
\hline Chamaephyte & Herbaceous and/or woody and persistent & $\begin{array}{l}\text { On or just above soil level but never more than } \\
0.5 \mathrm{~m} \text { above ground }\end{array}$ \\
\hline Geophyte & $\begin{array}{l}\text { Hemicryptophytes that survive unfavourable seasons in the form of } \\
\text { a rhizome, bulb, tuber or root bud }\end{array}$ & Below soil level \\
\hline Hemicryptophyte & $\begin{array}{l}\text { Herbaceous, often dying back after the growing season but with } \\
\text { buds or growth at soil level }\end{array}$ & Just on or below soil level \\
\hline Herbaceous phanerophyte & Herbaceous and persisting for several years & Above soil level \\
\hline Hydrophyte & $\begin{array}{l}\text { Vegetative shoots entirely in water, the leaves usually submersed } \\
\text { and/or floating; flower-bearing parts may emerge above the water }\end{array}$ & $\begin{array}{l}\text { Permanently or temporarily on the bottom of } \\
\text { the water }\end{array}$ \\
\hline Nanophanerophyte & Woody and indefinitely persistent & $\begin{array}{l}\text { Above soil level but normally less than } 3 \mathrm{~m} \\
\text { above ground }\end{array}$ \\
\hline Phanerophyte & Woody and indefinitely persistent & Normally $3 \mathrm{~m}$ or more above ground \\
\hline Therophyte & \multicolumn{2}{|c|}{ Plants surviving unfavourable seasons in the form of seeds, completing their life-cycle during the favourable season } \\
\hline
\end{tabular}

feasible and has been suggested for the Hawaiian genus Hillebrandia in the plant family Begoniaceae [27] and the fern genus Diellia [28].

\section{Correlates of lobelioid diversification}

In order to identify possible drivers of biotic diversification, it is essential to infer when and where lineages diversified. Ages and ancestral areas reconstructed here may, therefore, provide a suitable starting point for further examination of particular clades in the Lobelioideae.

One appealing example of how these reconstructions can be useful concerns the SCBL clade (Siphocampylus, Centropogon, Burmeistera and Lysipomia - clade N12 in Figure 3). This group of mainly nanophanerophytes and chamaephytes comprises over 580 species, which is about half of all Lobelioideae species $[21,23,29-31]$. The SCBL clade is entirely confined to the Neotropical region, and is particularly rich in species in the Northern Andes. The uplift of the Northern Andes began at $31 \mathrm{Ma}$ and intensified in the last $\sim 20 \mathrm{Ma}$, with several discrete phases of uplift which especially affected the Eastern Cordilleras [32]. The temporal match between the Andean uplift and the ages inferred here is striking: onset of diversification was inferred at $\sim 27 \mathrm{Ma}$ (PL) or $\sim 19 \mathrm{Ma}$ (BEAST) (Table 1) and the MRCA of this clade was unambiguously inferred as the Neotropics (Figure 9). Although a correlation in time and space does not necessarily imply causation, there is an emerging consensus that the Andean uplift has played a major role in Neotropical diversification [32-35]. Further studies are clearly needed in order to disentangle the rela- tive role of competing hypotheses of drivers of diversification in this clade, be they mainly abiotic (for example, geotectonic events, climatic fluctuations) or biotic (for example, pollinator interactions, such as those demonstrated for certain species of Centropogon and Burmeistera [36-40]).

The temporal framework for the Lobelioideae provided here may also contribute to the discussion on the diversification of particular Lobelioideae groups, for which a fine-scale biogeographic analysis has been performed but for which no absolute divergence times have been estimated. One of these is the giant lobelias of eastern Africa, which have been thoroughly studied by Knox and coworkers $[7,13,18,41]$. Crown ages for the eastern African clade, comprising Lobelia columnaris, L. gibberoa, and $L$. gregoriana, estimated here (in PL: mean $22.3 \mathrm{Ma} ; 13.7$ 30.4 Ma, 95\% CI; in BEAST: median 11.2 Ma; 3.09 - 20.8 Ma, 95\% HPD) clearly predate the age of most of the mountains in the Eastern and Western African Rifts [7]. These findings influence the interpretation of the tempo and possible processes underlying diversification in the region (see [7] for a detailed account on competing hypotheses and their predictions).

\section{Conclusion}

Let us recapitulate the thought-provoking hypothesis that the giant lobelias of Africa and the Hawaiian Islands converged into the giant life form from herbaceous ancestors in the same way as the giant senecios and the silversword alliance have (pages 84-85 in [4]; Figure 1). The distant 
Table 3: List of species used in the analyses of the Lobelioideae data set, their life form and distribution (simplified from Lammers [23]), and GenBank accession numbers.

\begin{tabular}{|c|c|c|c|c|c|c|}
\hline & Taxon & Life form & Distribution & rbcL & trnL-trnF & ITS \\
\hline I & Apetahia longistigmata & Nanophanerophyte & French Polynesia & DQ285272 & DQ285I55 & \\
\hline 2 & Apetahia margaretae & Nanophanerophyte & French Polynesia & DQ285286 & DQ285169 & \\
\hline 3 & Brighamia insignis & $\begin{array}{l}\text { Nanophanerophyte or } \\
\text { Phanerophyte }\end{array}$ & Hawaiian islands & AF042664 & DQ356189 & EU219385* \\
\hline 4 & Brighamia rockii & $\begin{array}{l}\text { Nanophanerophyte or } \\
\text { Phanerophyte }\end{array}$ & Hawaiian islands & $\underline{D Q 285257}$ & $\underline{D Q 285 \mid 40}$ & \\
\hline 5 & Burmeistera crispiloba & Nanophanerophyte & Neotropics & EFI7464I & DQ285164 & \\
\hline 6 & Burmeistera cyclostigmata & $\begin{array}{l}\text { Nanophanerophyte or } \\
\text { Chamaephyte }\end{array}$ & Neotropics & DQ356/47 & DQ356213 & \\
\hline 7 & Burmeistera domingensis & $\begin{array}{l}\text { Nanophanerophyte or } \\
\text { Chamaephyte }\end{array}$ & Neotropics & $\underline{D Q 356 \mid 48}$ & DQ356214 & \\
\hline 8 & Campanula asperuloides & Hemicryptophyte & Temp. Eurasia & DQ356117 & DQ356170 & \\
\hline 9 & Campanula latifolia & Hemicryptophyte & Temp. Eurasia & EFI4I027 & DQ356169 & \\
\hline 10 & Campanula trachelium & Hemicryptophyte & Temp. Eurasia & $\mathrm{DQ} 356118$ & DQ356171 & \\
\hline 11 & Canarina canariensis & Geophyte & Temp. Eurasia & $\overline{\mathrm{DQ} 356115}$ & DQ356167 & \\
\hline 12 & Centropogon cornutus & $\begin{array}{l}\text { Nanophanerophyte or } \\
\text { Chamaephyte }\end{array}$ & Neotropics & $\underline{D Q 356158}$ & DQ356226 & \\
\hline 13 & Centropogon dissectus & $\begin{array}{l}\text { Nanophanerophyte or } \\
\text { Chamaephyte }\end{array}$ & Neotropics & $\underline{E F I 41026}$ & DQ356215 & \\
\hline 14 & Centropogon gamosepalus & $\begin{array}{l}\text { Nanophanerophyte or } \\
\text { Chamaephyte }\end{array}$ & Neotropics & DQ356157 & DQ356225 & \\
\hline 15 & Centropogon granulosus & Nanophanerophyte & Neotropics & $\mathrm{DQ} 356152$ & DQ356220 & \\
\hline 16 & Centropogon gutierrezii & Chamaephyte & Neotropics & AF042658 & $\underline{D Q 285165}$ & \\
\hline 17 & Centropogon luteus & Nanophanerophyte & Neotropics & $\mathrm{DQ} 356151$ & DQ356219 & \\
\hline 18 & Centropogon trichodes & $\begin{array}{l}\text { Nanophanerophyte or } \\
\text { Chamaephyte }\end{array}$ & Neotropics & $\underline{D Q 356149}$ & DQ356217 & \\
\hline 19 & Clermontia arborescens & $\begin{array}{l}\text { Nanophanerophyte or } \\
\text { Phanerophyte }\end{array}$ & Hawaiian islands & $\underline{D Q 285258}$ & $\underline{D Q 285|4|}$ & \\
\hline 20 & Clermontia fauriei & $\begin{array}{l}\text { Nanophanerophyte or } \\
\text { Phanerophyte }\end{array}$ & Hawaiian islands & DQ285259 & DQ285I42 & \\
\hline 21 & Clermontia kakeana & $\begin{array}{l}\text { Nanophanerophyte or } \\
\text { Phanerophyte }\end{array}$ & Hawaiian islands & $\underline{L} 18789$ & DQ356172 & EU219386* \\
\hline 22 & Clermontia parviflora & Nanophanerophyte & Hawaiian islands & $\underline{D Q 285288}$ & $\underline{D Q 285171}$ & \\
\hline 23 & Cyanea acuminata & Nanophanerophyte & Hawaiian islands & DQ28526I & DQ285I44 & \\
\hline 24 & Cyanea angustifolia & $\begin{array}{l}\text { Nanophanerophyte or } \\
\text { Phanerophyte }\end{array}$ & Hawaiian islands & $\underline{D Q 356119}$ & DQ356173 & EU219384* \\
\hline 25 & Cyanea coriacea & $\begin{array}{l}\text { Nanophanerophyte or } \\
\text { Phanerophyte }\end{array}$ & Hawaiian islands & $\underline{\mathrm{AF} 042662}$ & DQ285I45 & \\
\hline 26 & Cyanea floribunda & Nanophanerophyte & Hawaiian islands & DQ285290 & DQ285173 & \\
\hline 27 & Cyanea hirtella & $\begin{array}{l}\text { Nanophanerophyte or } \\
\text { Phanerophyte }\end{array}$ & Hawaiian islands & $\underline{\mathrm{DQ} 285292}$ & DQ285175 & \\
\hline 28 & Cyanea koolauensis & Nanophanerophyte & Hawaiian islands & $\underline{D Q 356128}$ & $\underline{D Q 356193}$ & \\
\hline 29 & Cyanea kuhihewa & Nanophanerophyte & Hawaiian islands & DQ285294 & DQ285177 & \\
\hline 30 & Cyanea leptostegia & Phanerophyte & Hawaiian islands & $\mathrm{DQ} 285289$ & DQ285172 & \\
\hline 31 & Cyanea pilosa & Nanophanerophyte & Hawaiian islands & DQ285291 & DQ285174 & \\
\hline 32 & Delissea rhytidosperma & Nanophanerophyte & Hawaiian islands & AF042663 & DQ285I46 & \\
\hline 33 & Delissea subcordata & Nanophanerophyte & Hawaiian islands & DQ285264 & DQ285I47 & \\
\hline 34 & Delissea undulata & Phanerophyte & Hawaiian islands & & DQ356188 & EU219389* \\
\hline 35 & Diastatea micranta & Therophyte & Neotropics & $\underline{\mathrm{DQ} 356138}$ & DQ356203 & \\
\hline 36 & Downingia bacigalupii & Therophyte & N America & $\underline{E F \mid 41031}$ & DQ356183 & \\
\hline 37 & Downingia insignis & Therophyte & N America & EFI41030 & DQ356185 & \\
\hline 38 & Grammatotheca bergiana & Hemicryptophyte & Africa & $\mathrm{DQ356116}$ & DQ356168 & $\mathrm{AFI} 63429$ \\
\hline 39 & $\begin{array}{l}\text { Helianthus annuus - } \\
\text { Outgroup }\end{array}$ & (other) & (other) & AF0975I7 & A]430967 & \\
\hline 40 & Hippobroma longiflora & $\begin{array}{l}\text { Therophyte, Biennal or } \\
\text { Hemicryptophyte }\end{array}$ & Neotropics & $\underline{\mathrm{DQ} 356140}$ & DQ356206 & \\
\hline 41 & Isotoma axillaris & Hemicryptophyte & Oceania & DQ268874 & DQ285166 & \\
\hline 42 & Isotoma fluviatilis & Hemicryptophyte & Oceania & $\mathrm{DQ} 356161$ & DQ356230 & \\
\hline 43 & Jasione montana & Biennal or Therophyte & Temp. Eurasia & $\underline{\mathrm{DQ} 356120}$ & $\underline{D Q 356174}$ & \\
\hline 44 & Legousia hybrida & Therophyte & Temp. Eurasia & $\overline{\mathrm{DQ} 356163}$ & DQ356234 & \\
\hline
\end{tabular}


Table 3: List of species used in the analyses of the Lobelioideae data set, their life form and distribution (simplified from Lammers [23]), and GenBank accession numbers. (Continued)

\begin{tabular}{|c|c|c|c|c|c|c|}
\hline 45 & Lobelia aguana & $\begin{array}{l}\text { Nanophanerophyte or } \\
\text { Chamaephyte }\end{array}$ & Neotropics & $\mathrm{DQ} 356 / 22$ & DQ356176 & \\
\hline 46 & Lobelia anceps & Hemicryptophyte & & $\underline{D Q 356124}$ & DQ356184 & \\
\hline 47 & Lobelia angulata & Hemicryptophyte & Oceania & & AY568754+AY568744 & \\
\hline 48 & Lobelia aquatica & Aquatic & Neotropics & EFI41029 & DQ356182 & \\
\hline 49 & Lobelia arenaria & Hemicryptophyte & Oceania & & AY568756 + AY568737 & \\
\hline 50 & Lobelia boninensis & $\begin{array}{l}\text { Nanophanerophyte or } \\
\text { Herbaceous phanerophyte }\end{array}$ & Bonin Islands & AF042661 & DQ285I57 & \\
\hline 51 & Lobelia cardinalis & Hemicryptophyte & N America \& Neotropics & AF042659 & DQ356231 & \\
\hline 52 & Lobelia chinensis & $\begin{array}{l}\text { Hemicryptophyte or } \\
\text { Geophyte }\end{array}$ & Southeast Asia & & $\overline{\mathrm{DQ} 356228}$ & \\
\hline 53 & Lobelia columnaris & $\begin{array}{l}\text { Nanophanerophyte or } \\
\text { Herbaceous phanerophyte }\end{array}$ & Africa & DQ285275 & DQ285I58 & \\
\hline 54 & Lobelia cordifolia & Therophyte & Neotropics & & DQ356204 & \\
\hline 55 & Lobelia coronopifolia & Chamaephyte & Africa & $\underline{E F I 41025}$ & DQ356181 & \\
\hline 56 & Lobelia dortmanna & Aquatic & $\begin{array}{l}\text { N America \& Temp. } \\
\text { Eurasia }\end{array}$ & $\overline{D Q 356162}$ & DQ356232 & EU219388* \\
\hline 57 & Lobelia erinus & $\begin{array}{l}\text { Hemicryptophyte or } \\
\text { Therophyte }\end{array}$ & Africa & $\underline{L 01931}$ & DQ356233 & \\
\hline 58 & Lobelia exaltata & $\begin{array}{l}\text { Herbaceous phanerophyte or } \\
\text { Hemicryptophyte }\end{array}$ & Neotropics & $\mathrm{DQ} 356135$ & DQ356200 & EU219383* \\
\hline 59 & Lobelia excelsa & $\begin{array}{l}\text { Nanophanerophyte or } \\
\text { Phanerophyte }\end{array}$ & Neotropics & DQ356146 & DQ356212 & \\
\hline 60 & Lobelia fistulosa & $\begin{array}{l}\text { Herbaceous phanerophyte or } \\
\text { Chamaephyte }\end{array}$ & Neotropics & $\underline{D Q 356136}$ & DQ356201 & EU219387* \\
\hline 61 & Lobelia giberroa & Phanerophyte & Africa & DQ356/27 & DQ356192 & EU219380* \\
\hline 62 & Lobelia gloria-montis & Nanophanerophyte & Hawaiian islands & $\overline{\mathrm{DQ} 285265}$ & $\overline{\mathrm{DQ} 285 / 48}$ & \\
\hline 63 & Lobelia graniticola & Hemicryptophyte & Africa & $\underline{\mathrm{DQ} 356129}$ & DQ356194 & \\
\hline 64 & Lobelia gregoriana & $\begin{array}{l}\text { Nanophanerophyte or } \\
\text { Herbaceous phanerophyte }\end{array}$ & Africa & & $\overline{\mathrm{DQ} 356187}$ & EU219379* \\
\hline 65 & Lobelia hypoleuca & Nanophanerophyte & Hawaiian islands & $\underline{D Q 356126}$ & DQ356191 & \\
\hline 66 & Lobelia irasuensis & $\begin{array}{l}\text { Hemicryptophyte or } \\
\text { Geophyte }\end{array}$ & Neotropics & DQ356121 & $\overline{\mathrm{DQ} 356175}$ & AY362765 \\
\hline 67 & Lobelia kalmii & Hemicryptophyte & N America & DQ356166 & EFI 26736 & \\
\hline 68 & Lobelia kauaensis & Nanophanerophyte & Hawaiian islands & DQ285267 & $\overline{\mathrm{DQ} 285150}$ & \\
\hline 69 & Lobelia kraussii & Hemicryptophyte & Neotropics & EFI4I024 & $\underline{\mathrm{DQ} 356179}$ & \\
\hline 70 & Lobelia laxiflora & $\begin{array}{l}\text { Nanophanerophyte or } \\
\text { Chamaephyte }\end{array}$ & N America \& Neotropics & $\overline{D Q 356143}$ & $\overline{D Q 356209}$ & AY350631 \\
\hline 71 & Lobelia leschenaultiana & $\begin{array}{l}\text { Nanophanerophyte or } \\
\text { Chamaephyte }\end{array}$ & Southeast Asia & $\underline{D Q 356131}$ & DQ356196 & \\
\hline 72 & Lobelia macrodon & Hemicryptophyte & Oceania & EF694730 & AY568742 & \\
\hline 73 & Lobelia martagon & $\begin{array}{l}\text { Chamaephyte or } \\
\text { Hemicryptophyte }\end{array}$ & Neotropics & $\overline{D Q 356139}$ & $\overline{\mathrm{DQ} 356205}$ & \\
\hline 74 & Lobelia nicotianifolia & $\begin{array}{l}\text { Nanophanerophyte or } \\
\text { Herbaceous phanerophyte }\end{array}$ & Southeast Asia & AF042660 & $\underline{D Q 285161}$ & \\
\hline 75 & Lobelia niihauensis & Nanophanerophyte & Hawaiian islands & DQ285268 & $\underline{D Q 285151}$ & \\
\hline 76 & Lobelia nummularia & Hemicryptophyte & Southeast Asia & $\overline{\mathrm{DQ} 356164}$ & $\overline{\mathrm{DQ} 356235}$ & \\
\hline 77 & Lobelia oligophylla & Hemicryptophyte & Neotropics & DQ356159 & DQ356227 & \\
\hline 78 & Lobelia organensis & $\begin{array}{l}\text { Chamaephyte or } \\
\text { Hemicryptophyte }\end{array}$ & Neotropics & $\overline{\mathrm{DQ} 285279}$ & DQ285162 & \\
\hline 79 & Lobelia perpusilla & Hemicryptophyte & Neotropics & & AY56874I & \\
\hline 80 & Lobelia petiolata & Phanerophyte & Africa & DQ285280 & DQ285163 & \\
\hline 81 & Lobelia physaloides & $\begin{array}{l}\text { Nanophanerophyte or } \\
\text { Chamaephyte }\end{array}$ & Oceania & & $\overline{\text { AY568757 }}+$ AY568745 & \\
\hline 82 & Lobelia polyphylla & Nanophanerophyte & Neotropics & $\underline{D Q 356123}$ & DQ356177 & AY350633 \\
\hline 83 & Lobelia portoricensis & $\begin{array}{l}\text { Chamaephyte or } \\
\text { Hemicryptophyte }\end{array}$ & Neotropics & $\overline{\mathrm{DQ} 356142}$ & $\overline{\mathrm{DQ} 356208}$ & \\
\hline 84 & Lobelia purpurascens & $\begin{array}{l}\text { Hemicryptophyte or } \\
\text { Geophyte }\end{array}$ & Oceania & DQ356160 & DQ356229 & \\
\hline 85 & Lobelia rotundifolia & Nanophanerophyte & Neotropics & & DQ356178 & \\
\hline 86 & Lobelia roughii & Hemicryptophyte & Oceania & $\underline{D Q 356165}$ & EFI 26737 & \\
\hline 87 & Lobelia sonderiana & $\begin{array}{l}\text { Hemicryptophyte or } \\
\text { Therophyte }\end{array}$ & Africa & $\overline{D Q 356130}$ & $\overline{\mathrm{DQ} 356195}$ & \\
\hline
\end{tabular}


Table 3: List of species used in the analyses of the Lobelioideae data set, their life form and distribution (simplified from Lammers [23]), and GenBank accession numbers. (Continued)

\begin{tabular}{|c|c|c|c|c|c|c|}
\hline 88 & Lobelia stricklandiae & Phanerophyte & Africa & & DQ356186 & EU219381* \\
\hline 89 & Lobelia stricta & Hemicryptophyte & Neotropics & DQ356I4I & DQ356207 & \\
\hline 90 & Lobelia tomentosa & Chamaephyte & Africa & EFI41028 & DQ356180 & \\
\hline 91 & Lobelia tupa & $\begin{array}{l}\text { Chamaephyte or } \\
\text { Hemicryptophyte }\end{array}$ & Neotropics & $\mathrm{DQ} 356145$ & DQ35621I & \\
\hline 92 & Lobelia villosa & Nanophanerophyte & Hawaiian islands & DQ285293 & $\underline{D Q 285176}$ & \\
\hline 93 & Lobelia vivaldii & Nanophanerophyte & Neotropics & $\overline{D Q 268873}$ & DQ285167 & \\
\hline 94 & Lobelia xalapensis & Therophyte & Neotropics & $\mathrm{DQ} 356144$ & DQ356210 & \\
\hline 95 & Lobelia yuccoides & Nanophanerophyte & Hawaiian islands & DQ356125 & DQ356190 & \\
\hline 96 & Lysipomia cuspidata & Chamaephyte & Neotropics & $\overline{\mathrm{DQ} 356133}$ & $\overline{\mathrm{DQ} 356198}$ & AF054959 \\
\hline 97 & Lysipomia sphagnophila & Chamaephyte & Neotropics & DQ356132 & DQ356197 & AF054943 \\
\hline 98 & Sclerotheca forsteri & Nanophanerophyte & French Polynesia & DQ285287 & $\mathrm{DQ} 285170$ & \\
\hline 99 & Sclerotheca jayorum & $\begin{array}{l}\text { Nanophanerophyte or } \\
\text { Phanerophyte }\end{array}$ & French Polynesia & $\underline{\mathrm{DQ} 285273}$ & DQ285I56 & \\
\hline 100 & Siphocampylus affinis & $\begin{array}{l}\text { Nanophanerophyte or } \\
\text { Chamaephyte }\end{array}$ & Neotropics & $\underline{\mathrm{DQ} 356155}$ & DQ356223 & \\
\hline 101 & Siphocampylus brevicalyx & Nanophanerophyte & Neotropics & DQ356156 & DQ356224 & \\
\hline 102 & Siphocampylus fulgens & $\begin{array}{l}\text { Nanophanerophyte or } \\
\text { Chamaephyte }\end{array}$ & Neotropics & EFI4I032 & DQ356216 & \\
\hline 103 & Siphocampylus giganteus & $\begin{array}{l}\text { Nanophanerophyte or } \\
\text { Phanerophyte }\end{array}$ & Neotropics & $\underline{\mathrm{DQ} 356154}$ & DQ356222 & \\
\hline 104 & Siphocampylus macropodus & Nanophanerophyte & Neotropics & DQ356153 & DQ356221 & \\
\hline 105 & Siphocampylus scandens & Nanophanerophyte & Neotropics & $\mathrm{DQ} 356150$ & $\overline{\mathrm{DQ} 356218}$ & \\
\hline 106 & Solenopsis laurentia & Therophyte & Temp. Eurasia & $\overrightarrow{\mathrm{DQ} 356134}$ & DQ356199 & \\
\hline 107 & Trematolobelia kauaiensis & Nanophanerophyte & Hawaiian islands & $\overline{\mathrm{DQ} 285270}$ & $\overline{\mathrm{DQ} 285153}$ & \\
\hline 108 & Trematolobelia macrostachys & $\begin{array}{l}\text { Nanophanerophyte or } \\
\text { Phanerophyte }\end{array}$ & Hawaiian islands & $\underline{\mathrm{DQ} 356137}$ & DQ356202 & $\underline{E U 219382 *}$ \\
\hline
\end{tabular}

Sequences produced in this study are marked with $\left(^{*}\right)$; their origin and voucher information are available from their GenBank record.

relationship between Dendrosenecio and the silversword alliance, and their separate diversification, has been generally accepted for more than a century. This is reflected in their taxonomic placement in different tribes based on conspicuous floral dissimilarities and was recently corroborated by molecular phylogenetic analyses [42-45]. In contrast, the results presented here show a very different evolutionary history for the giant form in the subfamily Lobelioideae. The giant lobelioids of Africa and the Hawaiian Islands, together with similarly large species from eastern Brazil, French Polynesia and southeast Asia, are all derived from a single ancestor that was woody and probably African.

Detailed comparative studies are needed in order to evaluate the morphological similarities and differences in habits among and within clades N4, N10 and N12 (Figure 3 ). A different way of coding for the morphology and habits of species in those clades might affect the reconstruction of the ancestral states for the Lobelioideae. Eventually, more phylogenetically informative sequence data and denser taxon sampling may help elucidate the evolution of this exceedingly diverse plant group.

\section{Methods}

\section{Choice of taxa and molecular markers}

So far, some 2600 sequences classified as belonging to family Campanulaceae have been deposited in GenBank (as of August 2009). In order to assess which of these were correctly placed in subfamily Lobelioideae, I first downloaded all Campanulaceae accessions for the most widely used sequence regions: $r b c \mathrm{~L}$, $\operatorname{trn} \mathrm{L}-\mathrm{F}$ and ITS. Two criteria were then used for choosing the ingroup taxa in order to infer relationships within subfamily Lobelioideae: (i) that the species could be confidently assigned to the Lobelioideae based on the results from the large-scale analyses for the Campanulaceae; and (ii) that the $\operatorname{trn} \mathrm{L}-\mathrm{F}$ region was sequenced for that species, since this region has been shown to contain considerably more phylogenetically informative characters than $r b c \mathrm{~L}(41.7 \%$ as compared to $25.9 \%$, respectively [21]). Based on these criteria, a total of 108 species (including seven outgroup species) were then selected for inferring the phylogeny of the Lobelioideae. This represents an increase of 33 species compared to the high-level phylogeny of the Lobelioideae recently presented by Antonelli [21]. In that analysis, sequences for several taxa exhibiting a large/giant habit had not yet been made available on GenBank. These include representatives from the genera Apetahia and Sclerotheca (from French Polynesia), Lobelia boninensis (from the Bonin Islands), Lobelia sect. Galeatella (from the Hawaiian Islands) and Lobelia nicotianifolia (from southeast Asia), as well as many other herbaceous species.

In an attempt to increase the phylogenetic resolution among representatives of the giant lobelioids, sequences 


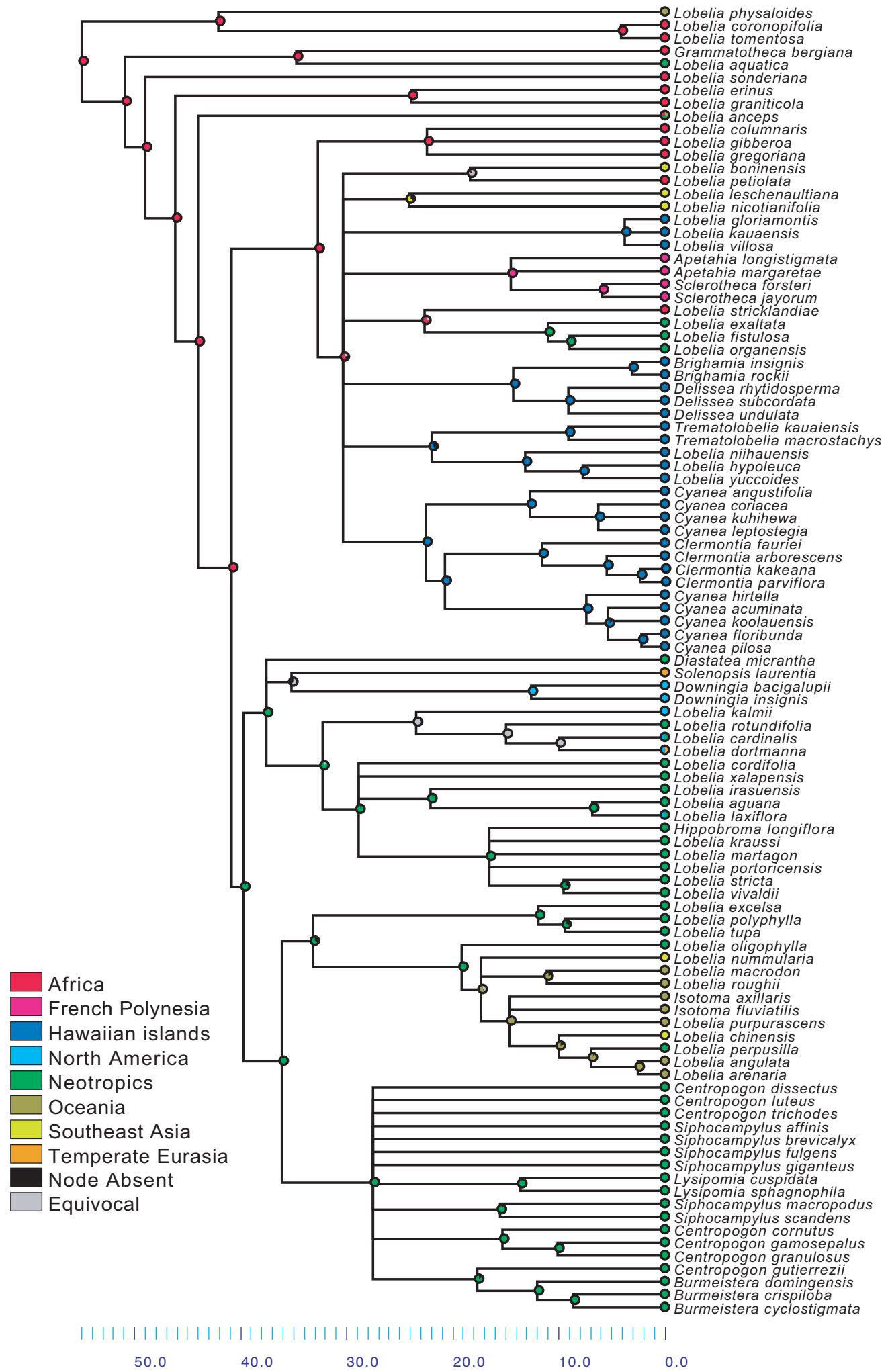

Figure 9

Ancestral range evolution in relation to time. Results from ancestral range reconstructions in subfamily Lobelioideae. Methodology as in Figure 7. 


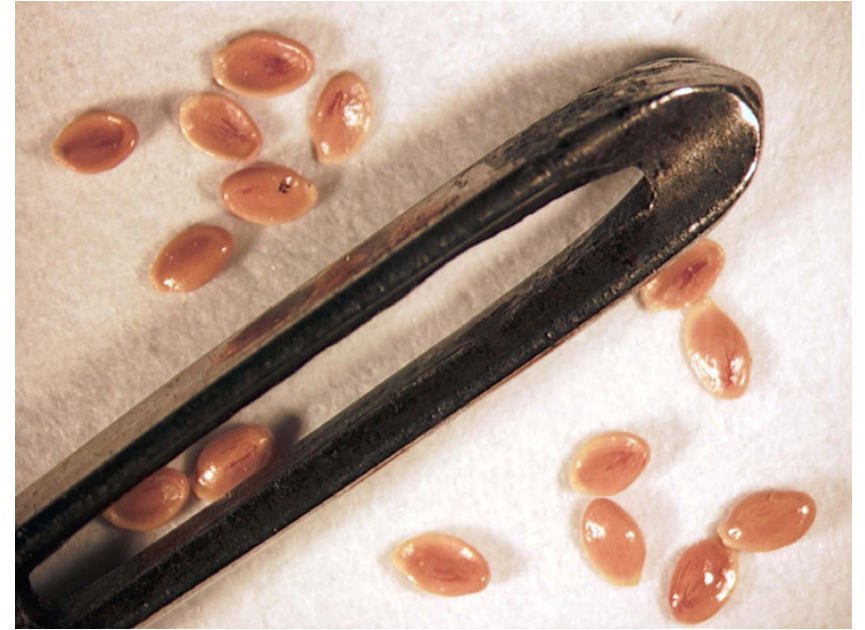

Figure 10

Tiny seeds crossing long distances. Lobelioid seeds are extremely small and could presumably be carried over large distances by strong wind currents. The figure shows seeds from the Hawaiian endemic Clermontia kakeana around the eye of a needle; one gram contains about 36,000 seeds.

of the ITS (ITS 1 - 5.8S - ITS 2) of nuclear ribosomal DNA were generated de novo for 10 giant species plus Lobelia dortmanna. The region was amplified and sequenced with the primers ITS1, ITS2, ITS3, ITS4 [46], and ITS10 [21], following the amplification and sequencing techniques described by Antonelli [21]. Since ITS is one of the fastest evolving molecular markers available today [47-49], its use was expected to add resolution for identifying the relationships between the main groups of giant lobelioids. Table 3 lists all species used in the analyses of subfamily Lobelioideae and indicates the species sequenced for this study.

\section{Alignment and phylogenetic estimation}

Sequences were aligned using the L-INS-I algorithm implemented in the software MAFFT v. 6 [50]. Aligned matrices were inspected manually and all unreliable sequences excluded, iteratively, until all sequences were deemed homologous. The final aligned matrices for Campanulaceae comprised: for trnL-F, 452 sequences and 1541 characters; for ITS, 445 sequences and 1197 characters; and for $r b c \mathrm{~L}$, 438 sequences and 1401 characters.

Maximum Likelihood trees were inferred in the software Garli 0.960 [51] by performing 10 independent runs with the default settings. The analyses were performed in the CIPRES cluster at the San Diego Supercomputer Center http://www.phylo.org/portal2 and the results visualized using the Interactive Tree of Life facility http:// itol.embl.de. MrModeltest $[52,53]$ was used to select the best-fitting evolutionary model for each sequence region.
The Partition Homogeneity Test [54] was applied to test for conflicting phylogenetic signal among these regions by performing a heuristic search with 5000 replicates, 100 random addition sequences, TBR branch swapping and saving up to 50 trees per replicate in PAUP* version $4.0 b 10$ [55]. Since the test did not approach significance $(P=0.962)$, the three markers were combined for the subsequent analyses. A bootstrap analysis was run in PAUP under the maximum parsimony criterion, by sampling 10000 replicates, with 100 random addition sequences and saving one tree per replicate. A Bayesian phylogenetic analysis was then conducted with the software MrBayes $\mathrm{v}$. 3.1 [56], performing two parallel runs of 20 million generations each, using four chains, sampling every 1000 generations and saving branch lengths. The performance of the analyses was evaluated using the software Tracer

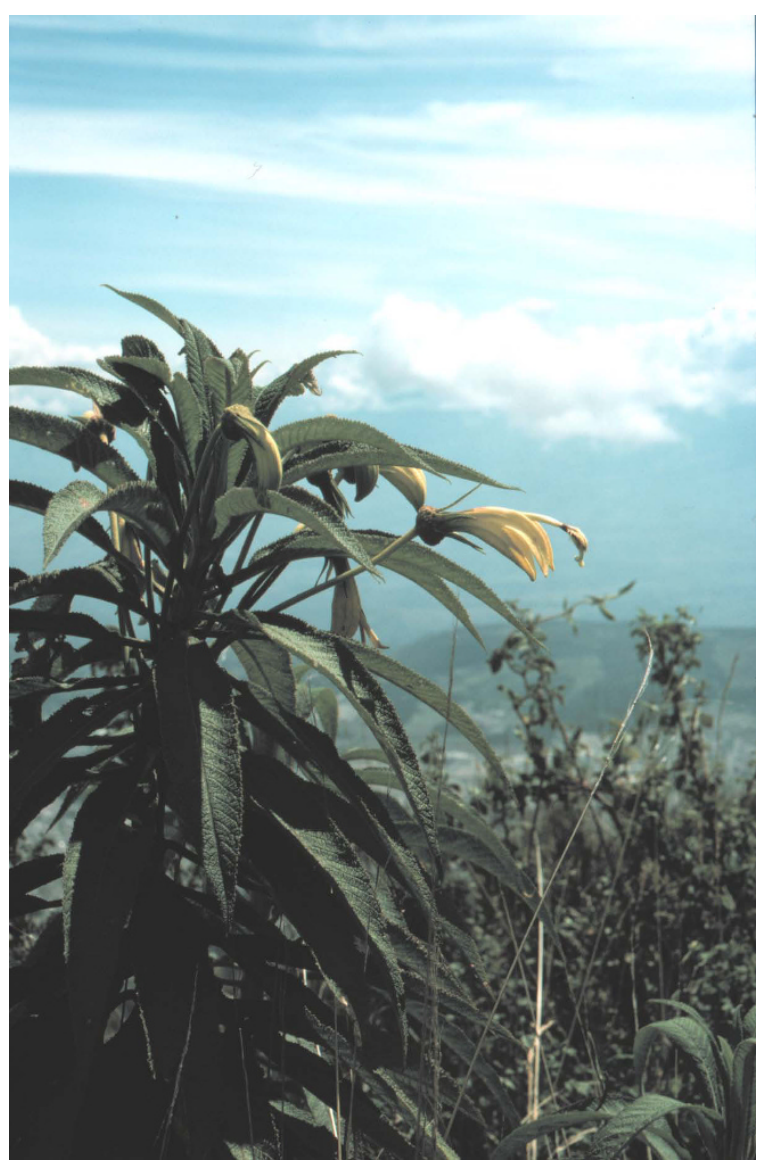

Figure I I

Large habit attained elsewhere. Although truly giant lobelioids (with a thick stem and a large terminal leaf rosette) all belong to the same clade, some Neotropical species in the genera Siphocampylus, Centropogon and Burmeistera can be rather tall shrubs. The Andean Siphocampylus giganteus portrayed here is one example which has been coded as varying between nanophanerophyte and phanerophyte. [Credit: Lennart Andersson]. 
v.1.4.1 [57] and node frequency statistics calculated on 20000 post burn-in trees.

\section{Molecular dating}

Several methods are currently available for estimating divergence times in a phylogeny $[58,59]$. In order to compare the results from two widely used methods, divergence times were estimated using the Bayesian relaxed clock and PL approaches [60,61]. Both methods have the advantage of enabling direct calibration on one or more nodes of a phylogeny. A major difference between them, however, is that PL assumes that rates are auto-correlated (inheritable), whereas in Bayesian relaxed clock dating each branch is allowed to evolve at its own rate.

PL estimations were done using the software r8s [61,62]. An automated cross-validation algorithm was run to identify the optimal smoothing value for the final analysis, with $\log _{10}$ increments of 0.1 and using the Truncated Newton method implemented in r8s. For estimating the effects of phylogenetic uncertainty on node age estimations, 1000 trees from the stationary sample of Bayesian trees were independently dated and their statistics (mean and 95\% confidence interval values) computed for each node of the Bayesian consensus tree using the software TreeAnnotator [63].

For the Bayesian dating analysis, five runs of 10 million generations each were performed in the software BEAST v.1.4.8 [22] at the Computational Biology Service Unit hosted by Cornell University, USA http://cbsuapps.tc.cor nell.edu. The analysis assumed a pure birth (Yule) process, since this tree prior is most suitable for inferring relationships between individuals from different species [22]. The performance of the analysis (convergence of the independent runs, effective sample sizes) was evaluated using Tracer v.1.4.1 [22]. Mean and 95\% HPD intervals of ages were then calculated from 40,000 post burn-in trees using the software TreeAnnotator v.1.4.8 [22], and visualized using FigTree v1.2.2 [63].

Three simultaneous calibration points were applied in both analyses. (i) Since the fossil record of Campanulaceae is exceptionally scarce [64], the root of the Asterales tree (see [65]) was calibrated at $93 \mathrm{Ma}$, as estimated under a major study including 83 asterid families and based on six plastid markers and six fossil calibrations [66]. Reliability of this age was recently corroborated by a study that employed the same set of fossils, but a different set of sequence regions and taxa (mean $94 \mathrm{Ma}$; [67]). In the PL analysis, $93 \mathrm{Ma}$ was set as a fixed calibration, whereas in the BEAST analyses it constituted a normally distributed prior with mean $93 \mathrm{Ma}$ and standard deviation of 1.0. (ii) An unchallenged fossil Campanula from the Miocene of Poland [68] was used to impose a minimal age constraint of 5.33 Ma for subfamily Campanuloideae. (iii) A 29.8 Ma maximum age was imposed for the radiation of the endemic Hawaiian taxa. This corresponds to the age of the oldest island of the Hawaiian Ridge (Kure), after which a continuous chain of islands has been available for propagules of the highland Hawaiian biota. In the PL analysis, this provided minimal ages for the five strongly supported $(\mathrm{Bpp}=1.00)$ crown groups of Hawaiian species identified in the MrBayes analysis (see Figure 4, Results). In order to be able to use the latter as a calibration point in the BEAST analyses, it first was necessary to constrain all Hawaiian species to be monophyletic (failure to do so caused the program to crash, apparently due to a failure in generating starting trees). Since the monophyly of the Hawaiian lobelioids was demonstrably strongly supported $[\mathrm{Bpp}=$ $1.00,8,10]$, this a priori constraint was not expected to significantly influence the results.

\section{Biogeographic and character evolution analyses}

One problematic aspect in referring to 'giant lobelioids' is how we should characterize these plants morphologically. Giant lobelias have been described as:

'pachycaul plants; often long-lived and pliestesial; of large stature and bulk; with dense apical rosettes of typically sessile leaves, which may close every night and are retained even after they die for insulation and fire protection; with nightly closing, large racemose inflorescences; with a large apical bud of developing leaves to protect young tissue; which secrete ice-nucleating polysaccharide fluids that prevent frost damage; and a hollow pith for internal water storage that narrows basipetally'. (see [7] and references therein $[23,69,70])$.

These features correctly describe several of the eastern African species but they do not apply to all of them, let alone to other large lobelioids elsewhere (for example, the Andean species Siphocampylus giganteus, Figure 11). To overcome this problem, life form was coded here according to the recent checklist of the Campanulaceae by Lammers [23] (Table 2). Besides being a comprehensive and up-to-date account on life form and distribution for all species, this work provides a consistent framework for evaluating evolutionary traits in the family. The current distribution of all species was compiled from the same source [23], but simplified into eight larger operational units: Africa, French Polynesia, the Hawaiian Islands, temperate North America, the Neotropical region including temperate South America, Oceania, southeast Asia and temperate Eurasia. For both characters, the outgroup taxon (Helianthus) was coded as having a different state to any of the ingroup taxa, to prevent biasing the reconstruction of basal nodes on the tree (since Helianthus is used here to root the Campanulaceae tree but it is certainly not 
the sister species to the Campanulaceae). Life form and distribution for all species analysed are listed in Table 3.

The most widely used methods of ancestral area reconstruction that are able to take into account phylogenetic uncertainty and multistate characters are Fitch Parsimony (FP), implemented in the software Mesquite v. 2.7 [71] and Bayes-DIVA $[72,73]$. These two methods are based on very different biogeographic evolutionary models. FP constrains ancestors to be monomorphic (that is, restricted to single areas) and models changes in distribution from ancestor to descendant as a change in character state, equivalent to dispersal between single areas. It thus implements a dispersalist explanation. In contrast, DIVA allows widespread distributions at ancestral nodes. Although the maximum number of areas can be constrained in DIVA, single-area ancestors are not allowed and widespread distributions are always divided at speciation events by vicariance. Thus DIVA favours a more vicariant explanation [74]. Based on the molecular dating results obtained (see Results and Discussion), and taking into consideration that the Hawaiian archipelago has never been connected to any land mass [26], it is clear that long-distance dispersals have played a crucial role in shaping the distribution of the Lobelioideae. This indicated that Fitch optimization was a more suitable method for inferring ancestral ranges of lobelioid nodes than DIVA. Mesquite v. 2.7 [71] was therefore used for reconstructing both ancestral areas and ancestral life forms. To take into account phylogenetic uncertainty, reconstructions were performed on 1000 trees from the stationary Bayesian tree sample, using the Maximum Parsimony criterion and counting all trees with uniquely best states. The results were summarized by computing the relative frequencies of ancestral area reconstructions for each node of the Bayesian consensus cladogram of the Lobelioideae.

\section{Tests of phylogenetic conservatism}

In order to test whether life form and geographic distribution were phylogenetically conservative, I first calculated the number of parsimony steps necessary to explain the occurrence of each character on a particular tree, repeating this for 1000 trees randomly chosen from the post burnin Bayesian sample (the same sample used for the dating and character state reconstruction analyses). I then generated 1000 trees with the same topology as the Bayesian $50 \%$ majority-rule consensus but with character states randomly shuffled among the tips of each tree, while keeping their relative frequency constant. The values obtained after reconstructing the characters on the simulated data set were used to compute $99 \%$ credibility intervals, to which the observed numbers of parsimony steps for each respective character could be compared. The analyses were performed in Mesquite v. 2.7 [71].

\section{Abbreviations}

BEAST: Bayesian evolutionary analysis by sampling trees; Bpp: Bayesian posterior probability; Bs: Bootstrap support; CI: Confidence interval; HPD: Highest Posterior Density; ITS: internal transcribed spacer; Ma: Megaannum (million years); MRCA: most recent common ancestor; PL: Penalized Likelihood; SCBL: Siphocampylus, Centropogon, Burmeistera, Lysipomia.

\section{Acknowledgements}

I would like to thank Roger Eriksson, Claes Persson, Aelys Humphreys, Bengt Oxelman, Thomas Lammers, Eric Knox, Uno Eliasson, Derrick Zwickl and Toby Pennington for fruitful discussions and advice, Vivian Aldén for laboratory assistance, and Gerald Carr, Frederick Warshauer and Christian Puff for kindly providing the photographs in Figure I. Thomas Givnish and three anonymous reviewers are kindly acknowledged for reviewing and providing constructive criticism on this manuscript. This research has been financially supported by grants from the Royal Swedish Academy of Sciences, the Swedish Research Council to Claes Persson, the Royal Society of Arts and Sciences in Göteborg, Kungliga och Hvitfeldtska Stiftelsen, Helge Ax:son Johnsons Stiftelse, Carl Tryggers Stiftelse and University of Gothenburg.

\section{References}

I. Linnaeus C: Systema Naturae Volume I. I0th edition. Laurentii Salvii, Holmiae; 1758:824.

2. Givnish TJ, Sytsma KJ: Molecular Evolution and Adaptive Radiation. Cambridge: Cambridge University Press; 1997.

3. Futuyma DJ, Edwards SV, John R: Evolution. Massachusetts: Sinauer Associates; 2005.

4. Hedberg O: Features of afroalpine plant ecology. Stockholm: Almqvist \& Wiksell; 1964.

5. Fries RE, Fries TCE: Die riesen-lobelien Africas. Svensk Botanisk Tidskrift 1922, 1 6:383-416.

6. Mabberley DJ: The giant lobelias: pachycauly, biogeography, ornithophily and continental drift. New Phytologist 1975, 74:365-374.

7. Knox EB, Palmer JD: Chloroplast DNA evidence on the origin and radiation of the giant lobelias in eastern Africa. Systematic Botany 1998, 23:109-149.

8. Givnish TJ: Adaptive radiation, dispersal, and diversification of the Hawaiian lobeliads. In The biology of biodiversity Tokyo: Springer; 1999:67-90.

9. Givnish TJ, Sytsma KJ, Smith JF, Hahn WJ: Thorn-like prickles and heterophylly in Cyanea: Adaptations to extinct avian browsers on Hawaii? Proceedings of the National Academy of Sciences of the United States of America 1994, 91 :2810-2814.

10. Givnish T], Millam KC, Mast AR, Paterson TB, Theim TJ, Hipp AL, Henss JM, Smith JF, Wood KR, Sytsma KJ: Origin, adaptive radiation and diversification of the Hawaiian lobeliads (Asterales: Campanulaceae). Proceedings of the Royal Society B: Biological Sciences 2009, 276:407-4I6.

II. Lammers TG: Chromosome numbers of Campanulaceae. III. Review and integration of data for subfamily Lobelioideae. Amer J Bot 1993, 80:660-675.

12. Lammers TG, Hensold N: Chromosome numbers of Campanulaceae. II. The Lobelia tupa complex of Chile. Amer J Bot 1992, 79:585-588.

13. Knox EB: The conservation status of the giant senecios and giant lobelias in eastern Africa. Opera Botanica 1993, I 2 I: $195-216$

14. Embuscado ME, BeMiller JN, Knox EB: A survey and partial characterization of ice-nucleating fluids secreted by giant-rosette (Lobelia and Dendrosenecio) plants of the mountains of eastern Africa. Carbohydrate Polymers 1996, 3 I: I-9.

15. Givnish TJ, Montgomery RA, Goldstein G: Adaptive radiation of photosynthetic physiology in the Hawaiian lobeliads: Light 
regimes, static light responses, and whole-plant compensation points. American Journal of Botany 2004, $91: 228-246$.

16. Montgomery RA, Givnish TJ: Adaptive radiation of photosynthetic physiology in the Hawaiian lobeliads: dynamic photosynthetic responses. Oecologia 2008, 155:455-467.

17. Montgomery RA, Goldstein G, Givnish T]: Photoprotection of PSII in Hawaiian lobeliads from diverse light environments. Functional Plant Biology 2008, 35:595-605.

18. Knox EB, Downie SR, Palmer JD: Chloroplast genome rearrangements and the evolution of giant lobelias from herbaceous ancestors. Molecular Biology and Evolution 1993, 10:4| 4-430.

19. Givnish TJ, Knox E, Patterson TB, Hapeman JR, Palmer JD, Sytsma KJ: The Hawaiian lobelioids are monophyletic and underwent a rapid initial radiation roughly $\mathbf{1 5}$ million years ago. American Journal of Botany 1996, 83:159.

20. Givnish TJ, Sytsma KJ, Smith JF, Hahn WJ: Molecular evolution, adaptive radiation, and geographic speciation in Cyanea (Campanulaceae, Lobelioideae). Hawaiian Biogeography: Evolution on a Hot Spot Archipelago 1995:288-337.

21. Antonelli A: Higher level phylogeny and evolutionary trends in Campanulaceae subfam. Lobelioideae: Molecular signal overshadows morphology. Molecular Phylogenetics and Evolution 2008, 46: $1-18$.

22. Drummond AJ, Rambaut A: BEAST: Bayesian evolutionary analysis by sampling trees. Bmc Evolutionary Biology 2007, 7:8.

23. Lammers TG: World Checklist and Bibliography of Campanulaceae. Kew: Royal Botanical Gardens; 2007.

24. Scotese CR: Atlas of Earth History. In Paleogeography Volume I. Arlington:PALEOMAP Project; $200 \mathrm{I}$.

25. Koren I, Kaufman YJ, Washington R, Todd MC, Rudich Y, Martins JV, Rosenfeld $D$ : The Bodélé depression: A single spot in the Sahara that provides most of the mineral dust to the Amazon forest. Environmental Research Letters 2006, I:

26. Clague DA: The growth and subsidence of the HawaiianEmperor volcanic chain. The origin and evolution of Pacific Island Biotas, New Guinea to Eastern Polynesia: pattern and processes 1996.

27. Clement WL, Tebbitt MC, Forrest LL, Blair JE, Brouillet L, Eriksson T, Swensen SM: Phylogenetic position and biogeography of Hillebrandia sandwicensis (Begoniaceae): a rare Hawaiian relict. American Journal of Botany 2004, 91:905-917.

28. Schneider H, Ranker TA, Russell SJ, Cranfill R, Geiger JMO, Aguraiuja R, Wood KR, Grundmann M, Kloberdanz K, Vogel JC: Origin of the endemic fern genus Diellia coincides with the renewal of Hawaiian terrestrial life in the Miocene. Proc $R$ Soc B-Biol Sci 2005, 272:455-460.

29. Lammers TG: Review of the neotropical endemics Burmeistera, Centropogon, and Siphocampylus (Campanulaceae: Lobelioideae), with description of 18 new species and a new section. Brittonia 1998, 50:233-262.

30. Lammers TG: Seventeen new species of Lobelioideae (Campanulaceae) from South America. Novon 2002, 12:206-233.

31. Knox EB, Muasya AM, Muchhala N: The predominantly South American clade of Lobeliaceae. Systematic Botany 2008 33:462-468

32. Wesselingh FP, Hoorn C, Kroonenberg SB, Antonelli A, Lundberg JG, Vonhof $\mathrm{HB}$, Hooghiemstra $\mathrm{H}$ : On the origin of Amazonian land scapes and biodiversity: a synthesys. In Amazonia, Landscape and Species Evolution Ist edition. Edited by: Hoorn, C, Wesselingh, FP. Oxford: Blackwell; 2010.

33. Antonelli A: Spatiotemporal Evolution of Neotropical Organisms: New Insights into an Old Riddle. In Doctoral Thesis University of Gothenburg, Department of Plant and Environmental Sciences, Göteborg, Sweden; 2008.

34. Antonelli A, Nylander JAA, Persson C, Sanmartín I: Tracing the impact of the Andean uplift on Neotropical plant evolution. Proceedings of the National Academy of Sciences 2009, 106:9749-9754.

35. Antonelli A, Quijada-Mascareñas A, Crawford AJ, Bates JM, Velazco PM, Wüster W: Molecular studies and phylogeography of Amazonian tetrapods and their relation to geological and climatic models. In Amazonia, Landscape and Species Evolution Ist edition. Edited by: Hoorn C, Wesselingh F. Oxford: Blackwell; 2010:386-404

36. Muchhala N: Exploring the boundary between pollination syndromes: Bats and hummingbirds as pollinators of Burmeistera cyclostigmata and B. tenuiflora (Campanulaceae). Oecologia 2003, 134:373-380.
37. Muchhala N: The pollination biology of Burmeistera (Campanulaceae): Specialization and syndromes. American Journal of Botany 2006, 93:108I-1089.

38. Muchhala N: Adaptive trade-off in floral morphology mediates specialization for flowers pollinated by bats and hummingbirds. American Naturalist 2007, 169:494-504.

39. Muchhala $\mathrm{N}$ : Nectar bat stows huge tongue in its rib cage. Nature 2006, 444:70I-702

40. Muchhala N, Potts MD: Character displacement among batpollinated flowers of the genus Burmeistera: analysis of mechanism, process and pattern. Proceedings of the Royal Society B: Biological Sciences 2007, 274:273I-2737.

4I. Knox EB, Luke Q, Thulin M: A new giant Lobelia from the Eastern Arc Mts, Tanzania. Kew Bulletin 2004, 59:189-194.

42. Knox EB, Palmer JD: Chloroplast DNA variation and the recent radiation of the giant senecios (Asteraceae) on the tall mountains of eastern Africa. Proceedings of the National Academy of Sciences of the United States of America 1995, 92: 10349-10353.

43. Knox EB, Palmer JD: The origin of Dendrosenecio within the Senecioneae (Asteraceae) based on chloroplast DNA evidence. American Journal of Botany 1995, 82: I567-1573.

44. Panero JL, Funk VA: The value of sampling anomalous taxa in phylogenetic studies: major clades of the Asteraceae revealed. Molecular Phylogenetics and Evolution 2008, 47:757-782.

45. Goertzen LR, Cannone JJ, Gutell RR, Jansen RK: ITS secondary structure derived from comparative analysis: implications for sequence alignment and phylogeny of the Asteraceae. Molecular Phylogenetics and Evolution 2003, 29:216-234.

46. White TJ, Bruns T, Lee S, Taylor J: Amplification and direct sequencing of fungal ribosomal RNA genes for phylogenetics. In PCR Protocols: a Guide to Methods and Applications London and New York: Academic Press; 1990:315-322

47. Hughes CE, Eastwood RJ, Bailey CD: From famine to feast? Selecting nuclear DNA sequence loci for plant species-level phylogeny reconstruction. Philosophical Transactions of the Royal Society B: Biological Sciences 2006, 36 I:2 I I-225.

48. Shaw J, Lickey EB, Beck JT, Farmer SB, Liu W, Miller J, Siripun KC Winder CT, Schilling EE, Small RL: The tortoise and the hare II: Relative utility of $\mathbf{2 I}$ noncoding chloroplast DNA sequences for phylogenetic analysis. American Journal of Botany 2005, 92:142-166

49. Shaw J, Lickey EB, Schilling EE, Small RL: Comparison of whole chloroplast genome sequences to choose noncoding regions for phylogenetic studies in angiosperms: the tortoise and the hare III. American Journal of Botany 2007, 94:275.

50. Katoh K, Kuma K-i, Toh H, Miyata T: MAFFT version 5: improvement in accuracy of multiple sequence alignment. Nucleic Acids Research 2005, 33:511-5I8.

5I. Zwickl DJ: Genetic algorithm approaches for the phylogenetic analysis of large biological sequence datasets under the maximum likelihood criterion. 2006 [http://www.bio.utexas.edu/fac ulty/antisense/garli/Garli.html]. PhD dissertation, The University of Texas at Austin

52. Nylander JAA: MrModeltest v2. Program distributed by the author. Evolutionary Biology Centre, Uppsala University; 2004.

53. Posada D, Crandall KA: MODELTEST: Testing the model of DNA substitution. Bioinformatics 1998, 14:817-818.

54. Farris JS, Kallersjo M, Kluge AG, Bult C: Testing significance of incongruence. Cladistics 1994, 10:315-319.

55. Swofford DL: PAUP*: phylogenetic analysis using parsimony (* and other methods). Version 2002.

56. Huelsenbeck JP, Ronquist F: MRBAYES: Bayesian inference of phylogenetic trees. Bioinformatics 200I, 17:754-755.

57. Rambaut A, Drummond Al: Tracer v/ 42007.

58. Renner SS: Relaxed molecular clocks for dating historical plant dispersal events. Trends in Plant Science 2005, 10:550-558.

59. Ricklefs RE: Estimating diversification rates from phylogenetic information. Trends in Ecology and Evolution 2007, 22:601-6I0.

60. Drummond AJ, Ho SYW, Phillips MJ, Rambaut A: Relaxed phylogenetics and dating with confidence. PLOS Biol 2006, 4:e88.

61. Sanderson MJ: Estimating Absolute Rates of Molecular Evolution and Divergence Times: A Penalized Likelihood Approach. Molecular Biology and Evolution 2002, 19:101-109.

62. Sanderson MJ: r8s: Inferring absolute rates of molecular evolution and divergence times in the absence of a molecular clock. Bioinformatics 2003, 19:301-302. 
63. Rambaut A]: FigTree vI.I. 2008 [http://tree.bio.ed.ac.uk/software/ figtree].

64. Lammers TG: Campanulaceae. In The families and genera of vascular plants Volume 8. Edited by: Kubitzki K. Berlin: Springer-Verlag; 2007:26-56.

65. Winkworth RC, Lundberg J, Donoghue MJ: Toward a resolution of Campanulid phylogeny, with special reference to the placement of Dipsacales. Taxon 2008, 57:53-65.

66. Bremer K, Friis EM, Bremer B: Molecular phylogenetic dating of asterid flowering plants shows Early Cretaceous diversification. Systematic Biology 2004, 53:496-505.

67. Janssens SB, Knox EB, Huysmans S, Smets EF, Merckx V: Rapid radiation of Impatiens (Balsaminaceae) during Pliocene and Pleistocene: Result of a global climate change. Molecular Phylogenetics and Evolution 2009, 52:806-824.

68. Lancucka-Srodoniowa M: Macroscopic plant remains from the freswater miocene of the Nowy Sacz Basin (West Carpathians, Poland). Acta Palaeobotanica 1979, XX:3-I 17.

69. Lammers TG: Revision of Lobelia sect. Galeatella (Campanulaceae: Lobelioideae). Journal of the Botanical Research Institute of Texas 2007, I:789-8I0.

70. Lammers TG: Revision of the endemic Hawaiian genus Trematolobelia (Campanulaceae: Lobelioideae). Brittonia 2009, 6I:126-143.

71. Maddison WP, Maddison DR: Mesquite: a modular system for evolutionary analysis. Version 2.0I. 2007 [http://mesquitepro jectorg].

72. Ronquist F: Dispersal-vicariance analysis: a new approach to the quantification of historical biogeography. Systematic Biology 1997, 46: 195-203.

73. Nylander JAA, Olsson U, Alström P, Sanmartín I: Accounting for Phylogenetic Uncertainty in Biogeography: A Bayesian Approach to Dispersal-Vicariance Analysis of the Thrushes (Aves: Turdus). Systematic Biology 2008, 57:257-268.

74. Sanmartin I: Event-based biogeography: Integrating patterns, processes, and time. In Biogeography in a Changing World Edited by: Ebach MC, Tangney R. Boca Raton: Crc Press-Taylor \& Francis; 2007:135-159.

Publish with Bio Med Central and every scientist can read your work free of charge

"BioMed Central will be the most significant development for disseminating the results of biomedical research in our lifetime. "

Sir Paul Nurse, Cancer Research UK

Your research papers will be:

- available free of charge to the entire biomedical community

- peer reviewed and published immediately upon acceptance

- cited in PubMed and archived on PubMed Central

- yours - you keep the copyright

Submit your manuscript here:

http://www.biomedcentral.com/info/publishing_adv.asp
BioMedcentral 